Review

\title{
Virus-Driven Carcinogenesis
}

\author{
Yuichiro Hatano ${ }^{1, *} \mathbb{0}$, Takayasu Ideta ${ }^{2,3}$, Akihiro Hirata ${ }^{4}$, Kayoko Hatano ${ }^{5}$, Hiroyuki Tomita ${ }^{1}{ }^{\mathbb{D}}$,

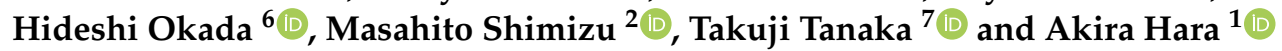

1 Department of Tumor Pathology, Gifu University Graduate School of Medicine, Gifu 501-1194, Japan; h_tomita@gifu-u.ac.jp (H.T.); ahara@gifu-u.ac.jp (A.H.)

2 Department of Gastroenterology, Gifu University Graduate School of Medicine, Gifu 501-1194, Japan; idetat@gifu-u.ac.jp (T.I.); shimim@gifu-u.ac.jp (M.S.)

3 Department of Laboratory Medicine, Gifu University Graduate School of Medicine, Gifu 501-1194, Japan

4 Laboratory of Veterinary Pathology, Joint Department of Veterinary Medicine, Faculty of Applied Biological Sciences, Gifu University, Gifu 501-1194, Japan; akatsuki@gifu-u.ac.jp

5 Department of Obstetrics and Gynecology, Gifu University Hospital, Gifu 501-1194, Japan; htnhtn@gifu-u.ac.jp

6 Department of Emergency and Disaster Medicine, Gifu University Graduate School of Medicine, Gifu 501-1194, Japan; hideshi@gifu-u.ac.jp

7 Department of Diagnostic Pathology (DDP) and Research Center of Diagnostic Pathology (RC-DiP), Gifu Municipal Hospital, Gifu 500-8513, Japan; takutt@gmhosp.gifu.gifu.jp

* Correspondence: yuha@gifu-u.ac.jp; Tel.: +81-58-230-6225

check for updates

Citation: Hatano, Y.; Ideta, T.; Hirata, A.; Hatano, K.; Tomita, H.; Okada, H.; Shimizu, M.; Tanaka, T.; Hara, A. Virus-Driven Carcinogenesis. Cancers 2021, 13, 2625. https://doi.org/ $10.3390 /$ cancers 13112625

Academic Editor: Karl Munger

Received: 30 April 2021

Accepted: 25 May 2021

Published: 27 May 2021

Publisher's Note: MDPI stays neutral with regard to jurisdictional claims in published maps and institutional affiliations.

\section{Copyright: (c) 2021 by the authors.} Licensee MDPI, Basel, Switzerland. This article is an open access article distributed under the terms and conditions of the Creative Commons Attribution (CC BY) license (https:// creativecommons.org/licenses/by/ $4.0 /)$.
Simple Summary: Carcinogens, causes of cancer, are usually invisible and therefore in vivo carcinogenesis is difficult to detect. Tumor viruses, definitive carcinogens, are also usually unremarkable, particularly due to latent infection. However, recent developments in tumor virology are unraveling how a single infected cell becomes a life-threatening cell population from a molecular perspective. The recognition and characterization of virus-driven carcinogenesis is the first step in the eradication of tumor virus-associated cancer.

Abstract: Cancer arises from the accumulation of genetic and epigenetic alterations. Even in the era of precision oncology, carcinogens contributing to neoplastic process are still an important focus of research. Comprehensive genomic analyses have revealed various combinations of base substitutions, referred to as the mutational signatures, in cancer. Each mutational signature is believed to arise from specific DNA damage and repair processes, including carcinogens. However, as a type of carcinogen, tumor viruses increase the cancer risk by alternative mechanisms, including insertional mutagenesis, viral oncogenes, and immunosuppression. In this review, we summarize virus-driven carcinogenesis to provide a framework for the control of malignant cell proliferation. We first provide a brief overview of oncogenic viruses and describe their implication in virus-related tumors. Next, we describe tumor viruses (HPV, Human papilloma virus; HBV, Hepatitis B virus; HCV, Hepatitis $C$ virus; EBV, Epstein-Barr virus; Kaposi sarcoma herpesvirus; MCV, Merkel cell polyoma virus; HTLV-1, Human T-cell lymphotropic virus, type-1) and tumor virus-related cancers. Lastly, we introduce emerging tumor virus candidates, human cytomegalovirus (CMV), human herpesvirus-6 (HHV-6) and adeno-associated virus-2 (AAV-2). We expect this review to be a hub in a complex network of data for virus-associated carcinogenesis.

Keywords: tumor virus; HPV; HBV; HCV; EBV; KSHV; MCV; HTLV-1; HIV-1

\section{Introduction}

Cancer is classified as a cell proliferative lesion according to its histology and primary site. However, cancer frequently shows variation among individuals and unique histological features, and no single histological type is identical to the others. Consistent with this notion, next-generation sequencing-based genomic analyses have shown that 
each histological cancer type shows intertumoral heterogeneity owing to genomic and epigenomic alterations in cancer-related genes. Such comprehensive analyses clarify not only the status of established cancer-related genes but also collateral factors, including tumor mutational burden and microsatellite instability. These additional factors are closely associated with past DNA damage and repair responses in cancer and play an important role in deciding optimal molecular therapies. These comprehensive analyses allow us to understand individual cancer in a chronological framework and, thus, the molecular classification of cancer is an emerging area in research and healthcare [1].

Will the emerging genomic classification really be the best and only approach in clinical oncology? Another approach for the classification of cancer is to investigate possible predisposing factors. These factors can be hereditary elements [2] and environmental factors, called carcinogens. Among carcinogens, oncogenic viruses predispose carriers to specific types of cancer in infected cells. Of note, studies of virus-driven carcinogenesis have generated insight into oncogenes [3] and thereby to carcinogenesis. Oncogenic viruses are a promising target for cancer prevention, diagnosis, and therapy.

In this review, we summarize virus-driven carcinogenesis to understand the malignant cell proliferation as controllable. We initially provide brief remarks on human viruses and oncogenic viruses. Next, we provide a detailed overview of every established virus-driven carcinogenesis. Lastly, we introduce miscellaneous infectious agents, including emerging tumor virus candidates.

\section{Overview of Tumor Viruses}

Inorganic particles that are infectious to humans, called human viruses, were discovered at beginning of the 20th century [4]. Despite possessing genetic information like other organisms, viruses fail to self-replicate. Viral replication requires an environmental factor, i.e., an appropriate host cell. Occasionally, virus activity leads to the illness and death of the host, resembling many ecological interactions. Owing to extensive research, the current virus taxonomy is highly complex and is beyond the scope of this review [5]; accordingly, we focus on the relationships between cancer and tumor viruses.

Tumor viruses, also called oncogenic viruses or oncoviruses, are associated with oneninth of cancer cases worldwide [6-9]. As summarized in Table 1, principal oncogenic viruses can be classified into six families. The International Agency for Research on Cancer (IARC) recognizes several tumor viruses as human carcinogens $[10,11]$. Hepatitis $B$ virus (HBV), hepatitis $\mathrm{C}$ virus (HCV), Epstein-Barr virus (EBV), Kaposi sarcoma herpesvirus (KSHV), human papilloma viruses (HPVs), especially type 16, and human T-cell lymphotropic virus, type-1 (HTLV-1) are classified as "carcinogenic to humans" (Group 1) [10]. Polyoma viruses were later added to the IARC monograph series. Merkel cell polyoma virus (MCV) is classified as "probably carcinogenic to humans" (Group 2A); BK virus and JC virus are classified as "possibly carcinogenic to humans" (Group 2B); SV40 virus is regarded as "not classifiable as to its carcinogenicity to humans"(Group 3) [11]. Recently, evidence for the carcinogenicity of MCV has accumulated [12]. 
Table 1. Summary of human tumor viruses.

\begin{tabular}{|c|c|c|c|c|c|c|c|}
\hline Variable & HPV & HBV & $\mathrm{HCV}$ & EBV & KSHV & MCV & HTLV-1 \\
\hline $\begin{array}{l}\text { Full Name/ } \\
\text { synonym }\end{array}$ & $\begin{array}{c}\text { Human } \\
\text { Papilloma } \\
\text { Virus }\end{array}$ & $\begin{array}{c}\text { Hepatitis B } \\
\text { Virus }\end{array}$ & $\begin{array}{c}\text { Hepatitis C } \\
\text { Virus }\end{array}$ & $\begin{array}{c}\text { Epstein-Barr } \\
\text { Virus/ } \\
\text { HHV-4 }\end{array}$ & $\begin{array}{c}\text { Kaposi } \\
\text { Sarcoma } \\
\text { Herpes } \\
\text { Virus/HHV-8 }\end{array}$ & $\begin{array}{c}\text { Merkel Cell } \\
\text { Polyoma } \\
\text { Virus }\end{array}$ & $\begin{array}{c}\text { Human } \\
\text { T-cell Lym- } \\
\text { photrophic } \\
\text { Virus, type-1 }\end{array}$ \\
\hline Family & Papillomaviridae & Hepadnaviridae & Flaviviridae & Herpesviridae & Herpesviridae & Polyomaviridae & Retroviridae \\
\hline $\begin{array}{l}\text { Baltimore } \\
\text { System }^{1}\end{array}$ & Class I & Class VII & Class IV & Class I & Class I & Class I & Class VI \\
\hline $\begin{array}{l}\text { Virus } \\
\text { Genome }\end{array}$ & dsDNA & ss/dsDNA & +ssRNA & lineardsDNA & circulardsDNA & dsDNA & $+\mathrm{RNA}$ \\
\hline $\begin{array}{l}\text { Genome } \\
\text { Size }\end{array}$ & $8 \mathrm{kbp}$ & $3 \mathrm{~kb} / \mathrm{kbp}$ & $9.5-12.5 \mathrm{~kb}$ & $170 \mathrm{kbp}$ & $170 \mathrm{kbp}$ & $5.4 \mathrm{kbp}$ & $9 \mathrm{kbp}$ \\
\hline $\begin{array}{l}\text { Virion } \\
\text { Size }\end{array}$ & $52-60 \mathrm{~nm}$ & $52-55 \mathrm{~nm}$ & $40-60 \mathrm{~nm}$ & $200 \mathrm{~nm}$ & $100-150 \mathrm{~nm}$ & $40-55 \mathrm{~nm}$ & $100 \mathrm{~nm}$ \\
\hline Envelope & Absent & Present & Present & Present & Present & Absent & Present \\
\hline Capsid & Icosahedral & Icosahedral & Icosahedral & Icosahedral & Icosahedral & Icosahedral & Icosahedral \\
\hline Vaccination & Accessible & Accessible & Inaccessible & Inaccessible & Inaccessible & Inaccessible & Inaccessible \\
\hline $\begin{array}{l}\text { Anti-viral } \\
\text { treatment }\end{array}$ & $\begin{array}{c}\text { Not } \\
\text { established }\end{array}$ & Effective & Effective & $\begin{array}{l}\text { Occasionally } \\
\text { Effective }\end{array}$ & $\begin{array}{c}\text { Not } \\
\text { established }\end{array}$ & $\begin{array}{c}\text { Not } \\
\text { established }\end{array}$ & $\begin{array}{c}\text { Not } \\
\text { established }\end{array}$ \\
\hline $\begin{array}{l}\text { Diagnostic } \\
\text { molecule }\end{array}$ & p16 & HBs antigen & $\begin{array}{l}\text { anti-HCV } \\
\text { antibody }\end{array}$ & EBER & LANA & CM2B4 & ATLA \\
\hline
\end{tabular}

1 The details of Baltimore system are found in refs. [13,14]. Abbreviations: ATLA, anti-adult T-cell leukemia/lymphoma antibody; ds, double strands; EBER, EBV-encoded small RNA; LANA, Latency-associated nuclear antigen; ss, single strand; +, positive sense.

Evidence for virus-driven carcinogenesis is summarized as follows [15]: the existence of viral DNA in tumor tissues, transformation by viral genes in model systems, generation of a neoplastic phenotype in response to the persistent expression of a vital oncogene or modification of host genes, and epidemiological data indicating that viral infections represent a major risk for carcinogenesis.

Although tumor viruses possess several "hallmarks of cancer" [16-18], there is a long lag between virus-driven carcinogenesis and the initial infection [19]. This slow neoplastic process can explain why the virus benefits from self-propagation, rather than host death.

Direct carcinogenicity of tumor viruses is due to insertional mutagenesis and viral oncogenes. Virus integration, distinct from viral contamination, is a cause of carcinogenesis [20]. Insertional mutagenesis refers to the alteration of gene structure or transcript levels by sequential alterations resulting from viral DNA integration. It is applicable to the constitutive expression of not only host but also viral genes. In contrast, expression of viral oncogenes acts as cancer driver genes in infected cells.

Indirect carcinogenicity of tumor viruses involves chronic inflammation and an immunosuppressive status arising from the infected cells. Chronic inflammation leads to DNA damage accumulation in tissue stem cells by repeated tissue injury and regeneration [21,22]. Some virus-associated cancers harbor specific DNA damage patterns, also called the mutational signatures $[23,24]$.

Immunosuppression/immunodeficiency is a risk factor for cancer, including virusdriven carcinogenesis [25]. Interestingly, most tumor viruses also attenuate the host immune state [18]. Consistent with this observation, the IARC classified human immunodeficiency virus, type 1 (HIV-1) as a Group 1 agent, indirectly associated with the cancer risk via immunosuppression [10]. A decrease in CD4+ T-cells by HIV-1 infection leads to acquired immunodeficiency syndrome (AIDS) [26]. Despite rapid progress in therapeutic strategies for HIV-1 [27], there is no established treatment to eliminate the retrovirus. In this clinical context, HIV-1 carriers and patients with AIDS develop other tumor virus-associated lesions [28].

Recently, the Pan-Cancer Analysis of Whole Genomes (PCAWG) Consortium reanalyzed the whole-genome sequencing data for 2656 cancer cases involving 38 tumor types [29]. Although clear evidence for the "hit-and-run theory" in human cancer has not been obtained [30], tumor viruses in cancer are detectable by massive DNA sequencing [31,32]. Consistent with the well-established etiologies, EBV is detected principally in head and neck, gastric, and esophageal cancers. HBV is associated with liver cancer. 
Alpha-papilloma viruses are found in head and neck and uterine cervical cancers, except for cases of non-specific viral contamination. In addition to tumor virus-associated events, transcripts from a human endogenous retrovirus, ERV1, are abundant in chronic lymphocytic leukemia and clear cell renal cell carcinoma [33].

\section{Diversity of Tumor Viruses}

In this section, we describe the details of virus-driven carcinogenesis according to viruses and their target organs (Table 2).

Table 2. Summary of virus-driven carcinogenesis.

\begin{tabular}{|c|c|c|c|}
\hline Virus & Target Organ & Tumor Type & Common Features \\
\hline \multirow{5}{*}{ High-risk HPVs } & Uterine cervix & $\begin{array}{l}\text { Squamous cell carcinoma } \\
\text { Adenocarcinoma }\end{array}$ & \multirow{5}{*}{ p16 positive, favorable prognosis } \\
\hline & $\begin{array}{l}\text { Head and neck } \\
\text { (oropharynx) }\end{array}$ & Squamous cell carcinoma & \\
\hline & Vagina & Squamous cell carcinoma & \\
\hline & Vulva & Squamous cell carcinoma & \\
\hline & Penis & Squamous cell carcinoma & \\
\hline HBV & Liver & $\begin{array}{l}\text { Hepatocellular carcinoma } \\
\text { Cholangiocellular carcinoma }\end{array}$ & $\begin{array}{l}\text { Frequent TP53 mutation } \\
\text { Small duct type }\end{array}$ \\
\hline \multirow{3}{*}{$\mathrm{HCV}$} & \multirow{3}{*}{$\begin{array}{c}\text { Liver } \\
\text { Hematopoietic system }\end{array}$} & Hepatocellular carcinoma & Frequent TERT mutation \\
\hline & & Cholangiocellular carcinoma & Small duct type \\
\hline & & Malignant lymphoma & Possible regression by viral elimination \\
\hline \multirow{4}{*}{$\begin{array}{l}\text { EBV/ } \\
\text { HHV-4 }\end{array}$} & Stomach & \multirow{4}{*}{$\begin{array}{c}\text { Adenocarcinoma } \\
\text { Nasopharyngeal carcinoma } \\
\text { See Tables } 3 \text { and } 4 \\
\text { EBV-associated smooth muscle } \\
\text { tumor }\end{array}$} & EBER positive, frequent TILs \\
\hline & Nasopharynx & & EBER positive, frequent TILs \\
\hline & Hematopoietic system & & EBER positive \\
\hline & Soft tissue & & EBER positive \\
\hline $\begin{array}{l}\text { KSHV/ } \\
\text { HHV-8 }\end{array}$ & $\begin{array}{c}\text { Soft tissue } \\
\text { Hematopoietic system }\end{array}$ & $\begin{array}{l}\text { Kaposi sarcoma } \\
\text { See Table } 5\end{array}$ & LANA positive \\
\hline $\mathrm{MCV}$ & Skin & Merkel cell carcinoma & CM2B4 positive \\
\hline HTLV-1 & Hematopoietic system & Adult T-cell leukemia/lymphoma & Frequent CCR4 mutation \\
\hline
\end{tabular}

Abbreviations: EBER, EBV-encoded small RNA; LANA, Latency-associated nuclear antigen; TILs, Tumor infiltrating lymphocytes.

\subsection{Human Papilloma Virus (HPV)}

Dermatotropic HPV was first isolated from a skin wart in 1973 [34] and a mucosotropic type, also called type 16, was subsequently identified from a cervical cancer sample by the research group of Dr. Zur Hausen [35]. At the beginning of the 21st century, more than 100 types of papilloma virus were identified [36]. HPVs, including alpha- and betapapillomaviruses, principally infects the squamous epithelium of the human mucosa and skin. Persistent HPV infection leads to squamous proliferative lesions, also called verruca/wart, papilloma, and condyloma [37,38].

Occasionally, HPV-related lesions give rise to malignant tumors due to the unique genomic characteristics of the high-risk HPV type. According to the IARC monograph, high-risk HPVs, which belong to alpha-papillomavirus, are types 16, 31, 52, 58 (clade A9); 18, 45, 59 (clade A7); 51 (clade A5); 56, 66 (clade A6) [39]. Of these HPVs, types 16 and 18 are the main causes of cervical cancer via the activation of oncogenes E6 and E7. In brief, E6 induces ubiquitination-mediated p53 degradation and, thus, blocks the p53 pathway [40-42]. In contrast, E7 inactivates the Rb pathway by calpain-mediated proteasomal degradation $[43,44]$. In addition, these oncoproteins function as immunosuppressors by the blockade of interferon pathways [45-48], indicating that the immunomodulatory effects promote the persistent infection of high-risk HPVs that initiates neoplastic change.

The integration of HPV into the human genome is an essential step in cervical carcinogenesis. This event leads to not only insertional mutagenesis but also to the persistent expression of the viral oncoproteins E6 and E7 [49]. HPV integration frequently occurs at fragile sites [50]. A recent genomic analysis revealed that the integration sites contain 
microhomologous sequences [51], a cause of microhomology-mediated break-induced replication [52].

Although HPV-associated cancer occurs in various body parts, including the oral cavity [53], anus [54], vagina [55], vulva [56], and penis [57], we focus only on two major cancer types, cancers of the uterine cervix [58] and head and neck [59].

A prototypical HPV-related carcinoma, cervical cancer had the fourth highest incidence and mortality rate among female cancers in 2020 [60]. Cervical cancer is almost always associated with high-risk HPVs and approximately a quarter of cases harbor an PIK3CA mutation, especially E542K and E545K [61]. These mutations link the APOBEC family gene-related mutational signature with HPV-related carcinogenesis [62-64].

Based on accumulating evidence, the most recent WHO classification regards HPVindependent cervical cancer as a distinctive diagnostic entity [65]. Interestingly, these HPVnegative categories include not only squamous lesions but also glandular lesions $[66,67]$ and neuroendocrine carcinoma [68]. These entities are considered an unfavorable prognostic group [69] and alternative forms of carcinogenesis. Therefore, the dual model of cervical carcinoma is reasonable for clinical practice and translational research. To determine whether cervical carcinoma is associated with high-risk HPV, the surrogate marker $\mathrm{p} 16$ is used in practice [70]. The overexpression of p16 arises from $\mathrm{Rb}$ inactivation by the viral oncogene E7 [71]. To eliminate HPV-positive cervical cancer, the main strategy consists of three preventive tactics: HPV vaccination, screening, and surgical treatment for precancerous lesions [72].

Similar to genital lesions, an association between HPV and laryngeal papilloma was reported in the 1980s [73]. A small subset of cases of head and neck cancer, especially oropharyngeal tumors, is also associated with HPV [74,75]. Consistent with cervical cancer, p16 positivity is a diagnostic marker for HPV-associated squamous cell carcinoma. Histologically, HPV-related head and neck cancer is a non-keratinizing type squamous cell carcinoma [76]. A recent TCGA comprehensive analysis [75] revealed that HPV-positive head and neck squamous cell carcinomas (HPV+HNSCC) are distinct from HPV-negative squamous cell carcinomas (HPV-HNSCC), which are probably related to the other carcinogens, including alcohol and tobacco [77]. HPV+HNSCC sometimes shows deletions or truncating mutations in TRAF3, involved in anti-viral responses [78]. HPV+HNSCC harbors a low frequency of TP53 mutations and is associated with a relatively favorable prognosis comparing with that of TP53-mutated and/or CCND1-amplified HPV-HNSCC. HPV+HNSCC harbors rare alterations of $C D K N 2$, which encodes p16, whereas HPV-HNSCC commonly lacks the 9p21.3 region, including CDKN2. Consistent with findings for cervical cancer, the genomic integration of HPV is randomly detected in $80 \%$ of HPV+HNSCC.

In contrast, the frequency of TP53 mutations in HPV-HNSCC is high (84\%) [75]. TP53 mutations in HPV-negative squamous cell carcinoma are reproducible events in other organs [79-82]. In addition, aberrant p53 expression has been reported in several premalignant lesions [83-86]. These observations suggest that the dysregulation of p53 is an essential and/or early step in squamous cell carcinogenesis.

\subsection{Hepatitis Virus}

Liver cancer ranks sixth and fourth in incidence and mortality, respectively, in the world, with an estimated 905,677 new cases and 830,180 deaths in 2020 [60]. The most common cancer type of liver cancer is hepatocellular carcinoma (HCC), which arises from a well-established cause in most cases [87]. HCC is associated with chronic liver disease, including persistent hepatitis B virus (HBV) and/or hepatitis $\mathrm{C}$ virus (HCV) infection $[88,89]$. In the following sections, we describe the features of each hepatitis virus.

\subsubsection{Hepatitis B Virus (HBV)}

The discovery of Australia antigen, now known as HBs, in 1964 initiated HBV research [90]. The subsequent discovery of HBV particles by Dane in 1970 [91] was followed by the cloning of HBV [92]. HBV is subclassified into nine genotypes [93], which are asso- 
ciated with clinical and epidemiological features [94]. This genetic variation is probably due to reverse transcription in viral replication [95]. Similarly, the genomic integration of $\mathrm{HBV}$ into host DNA frequently occurs, indicating that insertional mutagenesis is a major oncogenic event in HBV-related carcinogenesis [96]. The HBV integration breakpoints are random, except for several hotspots [97]. Rapid progress has been made in preventive and therapeutic interventions aimed at suppressing HBV infection and hepatitis [98-100].

$\mathrm{HCC}$ is a heterogeneous malignancy with respect to both morphological and genetical features [101]. A recent genomic analysis revealed the features of HCC [97,102-104]. The common driver events in HCC are the dysregulation of p53, TERT, and WNT pathways, principally due to mutations in TP53, the TERT promotor, and CTNNB1, respectively [105-107]. Consistent with the features of HBV, the majority of HCC cases show genomic integration of HBV [97]. Compared with the other etiology, HBV-related HCC frequently involves insertional mutagenesis, including mutations in KMT2B [108,109], KMT2D [104], CCND1 [104], CCNE1 [104], and TERT. Indeed, one-third of TERT dysregulation events arise from HBV integration [102]. In contrast, there is no clear evidence for HBV integration-associated copy number amplification [102]. In addition, the frequency of TP53 mutations in HBV-related HCC is high [103]. A recent TCGA analysis suggested that there is an association between HBV infection and exposure to Aflatoxin A, a liver carcinogen [104].

$\mathrm{HBV}$ is also a risk factor for small duct type intrahepatic carcinoma, which shows a biliary phenotype $[110,111]$. Although the origin of this cancer is considered liver progenitor cells [112] or transdifferentiated mature hepatocytes [113], the premalignant lesion remains unclear. Unlike HCC, this cancer typically express biliary markers EMA, CK7, and CK19, and lacks hepatocytic markers, including HepPar-1 and AFP. Unique genomic features of small duct type intrahepatic carcinoma are IDH1/2 [114] and BRAF mutations and FGFR2 translocation [111]. In addition, HBV-associated intrahepatic adenocarcinoma also harbors frequent TP53 mutations [115].

\subsubsection{Hepatitis C Virus (HCV)}

In 1989, the genetic sequence derived from HCV was first isolated as a transfusionmediated hepatitis virus, unrelated to hepatitis A virus or HBV [116]. The majority of non-A, non-B hepatitis is due to HCV [117]. These research milestones have contributed the reduction of transfusion-mediated hepatitis. The sequence of the HCV genome was then completed by the two groups [118,119], and HCV-induced hepatitis was finally demonstrated by an in vivo animal experiment [120]. Further evolution of HCV experimental models [121,122] has resulted in the development of novel therapeutic agents. A combination of direct acting antivirals (DAAs) has replaced standard interferon-based treatment [123].

Unlike HBV, HCV clearly induces hepatitis [124]. In addition to indirect effects [125], several HCV proteins have oncogenic properties [126-128]. Therefore, HCV eradiation by DAAs suppresses hepatocellular carcinogenesis $[129,130]$. However, liver cirrhosis confers a cancer risk after the elimination of the virus.

Although both HBV and HCV predispose patients to liver malignant neoplasia via chronic liver damage, HBV-associated HCC is believed to have high oncogenic potential. The frequencies of TERT promotor mutations and p16 silencing are higher for HCVassociated HCC than for HBV-associated and non-viral HCC [102]. In addition, HCV and HBV show distinct methylation patterns [104]. The virus infection status, for both HBV and HCV, is unrelated to the HCC immunophenotype, including checkpoint genes [104].

Epidemiological data suggest that HCV infection is associated with a predisposition towards small duct type intrahepatic cholangiocarcinoma [131] and malignant lymphoma [132]. Interestingly, these lymphomas sometimes regress after HCV elimination by antiviral agents $[133,134]$. A possible mechanism underlying lymphomagenesis is immune reactions between viral antigens and lymphocyte receptors. 


\subsection{Epstein-Barr Virus (EBV/HHV-4)}

EBV, classified as a human herpesvirus 4 (HHV-4), was first isolated from Burkitt lymphoma (BL) by Epstein and Barr in 1964 [135]. A ubiquitous infectious agent, EBV initially infects B-cells or epithelial cells [136]. The infection pattens of EBV are divided in latent and lytic infection. In latent infection, EBV exists as an episome in the nuclei of infected cells. The latent infection is further classified into latency I-III [137], according to the expression patterns of latent genes (Table 3).

Table 3. The latency patterns of EBV-associated cancers.

\begin{tabular}{|c|c|c|c|}
\hline Variable & Latency I & Latency II & Latency III \\
\hline EBER & Positive & Positive & Positive \\
\hline EBNA1 & Positive & Positive & Positive \\
\hline EBNA2 & Negative & Negative & Positive \\
\hline LMP1 & Negative & Positive & Positive \\
\hline \multirow{8}{*}{ Histological type } & \multirow{8}{*}{$\begin{array}{l}\text { Burkitt lymphoma } \\
\text { EBV+ gastric cancer }\end{array}$} & CHL $(50 \%)$ & \\
\hline & & EBV+DLBCL (common) & $\mathrm{EBV}+\mathrm{SMT}$ \\
\hline & & CAEBV/HVLPD/SMBA & $\mathrm{EBV}+\mathrm{DLBCL}$ (uncommon) \\
\hline & & PEL & LYG \\
\hline & & ENKTL & PAL/FA-DLBCL \\
\hline & & NPC & PTLD \\
\hline & & AITL & OI-LPD (uncommon) \\
\hline & & OI-LPD (common) & \\
\hline
\end{tabular}

Abbreviations: AITL, Angioimmunoblastic T-cell lymphoma; CAEBV, Chronic active HBV infection of T- and NK-cell type, systemic form; CHL, Classical Hodgkin lymphoma; EBER, EBV-encoded small RNA; EBNA, EBV-encoded nuclear antigen; EBV+DLBCL, EBV-positive diffuse large cell B-cell lymphoma, not otherwise specified (NOS); EBV+SMT, EBV-associated smooth muscle tumor; ENKTL, Extranodal NK/T-cell lymphoma, nasal type; FA-DLBCL, Fibrin-associated diffuse large cell B-cell lymphoma; HVLPD, Hydroa vacciniforme-like lymphoproliferative disorders; LMP, Late membrane protein; LYG, Lymphomatoid granulomatosis; NPC, Nasopharyngeal carcinoma; OI-LPD, Other iatrogenic lymphoproliferative disorder; PAL, Pyotholax-associated lymphoma; PEL, Primary effusion lymphoma; SMBA, severe mosquito bite allergy; PTLD, Post-transplant lymphoproliferative disorders.

To detect the latency pattern, immunostaining is used in clinical settings. EBNA2 expression is only found in latency III cells, whereas a lack of LMP1 indicates latency I cells. LMP1 induces the transformation of infected B-cells by activating CD40 signaling [138], whereas the transcription factor EBNA2 upregulates LMP1 expression $[139,140]$. Regardless of the latency pattern, EBV-encoded small RNA (EBER) [141-143] is consistently detected in EBV-infected cells [144]. Therefore, in situ hybridization for EBER is the most sensitive detection method for EBV-infected cells [145]. In the lytic infection, the sequential reactivation of lytic genes leads to the production of virus particles in order to propagate viral infection [146].

In 1958, Denis Burkitt reported a case series of pediatric small round cell tumors of the jaw [147]. BL is a truly B-cell malignancy whose histological pattern is described as a jigsaw puzzle or starry sky. The immunophenotype of BL shows the latency I pattern, indicating that the pathogenesis requires minimal latent proteins, EBER [148,149] and EBNA1 [150,151]. Rather, the driving force of BL is $c-m y c$ translocation, which is almost always detected in all three clinical types; endemic and sporadic BL and BL in immunocompromised hosts [152]. In addition, BL frequently has TCF3 and ID3 mutations [153-156]. $\mathrm{BL}$ is a highly aggressive tumor and is possibly curable by massive chemotherapy.

In addition to BL, various hematolymphoid neoplasms and/or proliferative disorders can be consolidated as EBV-associated diseases [152]. As shown in Table 4, EBV-associated hematolymphoid diseases consist of various diagnostic entities, including neoplasia of B-cell and NK/T-cell lineages, classical Hodgkin lymphoma, lymphoproliferative disorders, and infectious and reactive lesions. The clonality of EBV-associated lesions is demonstrable by the sequential analysis of EBV termini [157]. Notably, for each EBV-positive tumor, the EBV-negative counterpart and/or mimicry should be ruled out. For example, in a case of EBV-negative BL mimicry, Burkitt-like lymphoma has an 11q aberration without a MYC translocation [158,159]. EBV-associated lesions also include reactive lesions, probably due to EBER-mediated TLR3 signaling [160]. To understand the diversity of EBV-related hematolymphoid lesions, the precise classification based on the EBV infection status is essential. 
Table 4. Association between hematolymphoid lesions and EBV.

\begin{tabular}{|c|c|c|c|c|c|c|}
\hline Category & $\begin{array}{l}\text { Diagnostic Entity } \\
\text { (Abbreviation) }\end{array}$ & Clonality & Common Features & References & $\begin{array}{l}\text { Virus Negative } \\
\text { Mimicry }\end{array}$ & References \\
\hline B & Burkitt lymphoma & Monoclonal & $\begin{array}{c}\text { MYC translocation, } \\
\text { Ki-67 99\% }\end{array}$ & $\begin{array}{c}{[135,147,153-} \\
156]\end{array}$ & $\begin{array}{l}\text { Burkitt-like lymphoma } \\
\text { with } 11 \text { q aberration }\end{array}$ & {$[158,159]$} \\
\hline B & $\begin{array}{l}\text { EBV-positive diffuse large B-cell } \\
\text { lymphoma, not otherwise } \\
\text { specified (NOS) (EBV+DLBCL) }\end{array}$ & Monoclonal & $\begin{array}{l}\text { B-cell markers (CD19, } \\
\text { CD20, CD22, CD79)+, } \\
\text { MUM1+, CD10- }\end{array}$ & [161-163] & $\begin{array}{l}\text { Diffuse large B-cell } \\
\text { lymphoma, NOS } \\
\text { (DLBCL) }\end{array}$ & [164] \\
\hline B & $\begin{array}{c}\text { EBV-positive mucocutaneous } \\
\text { ulcer (EBVMCU) }\end{array}$ & Variable & $\begin{array}{l}\text { Immunosuppression, } \\
\text { methotrexate }\end{array}$ & [165] & $\begin{array}{l}\text { Diffuse large B-cell } \\
\text { lymphoma, NOS } \\
\text { (DLBCL) }\end{array}$ & [164] \\
\hline B & $\begin{array}{c}\text { Pyotholax-associated lymphoma } \\
\text { (PAL) }\end{array}$ & Monoclonal & $\begin{array}{l}\text { PAX5+, TP53 mutation, } \\
\text { MYC amplification }\end{array}$ & {$[166-169]$} & $\begin{array}{l}\text { Primary effusion } \\
\text { lymphoma (PEL) }\end{array}$ & {$[170,171]$} \\
\hline B & $\begin{array}{c}\text { Fibrin-associated diffuse large } \\
\text { B-cell lymphoma } \\
\text { (FA-DLBCL) }\end{array}$ & Monoclonal & $\begin{array}{l}\text { CD30+, MUM1+, } \\
\text { PD-L1+, intact } M Y C\end{array}$ & {$[172,173]$} & $\begin{array}{l}\text { Primary effusion } \\
\text { lymphoma (PEL) }\end{array}$ & {$[170,171]$} \\
\hline B & $\begin{array}{l}\text { Lymphomatoid granulomatosis } \\
\text { (LYG) }\end{array}$ & Variable & $\begin{array}{l}\mathrm{CD} 20+, \mathrm{CD} 30+/- \\
\mathrm{CD} 15-\end{array}$ & {$[174,175]$} & $\begin{array}{c}\text { Granulomatosis with } \\
\text { polyangiitis (Wegener's) }\end{array}$ & [176] \\
\hline B & Plasmablastic lymphoma & Monoclonal & $\begin{array}{c}\text { EBER+/-, } \\
\text { MYC translocation }\end{array}$ & {$[177,178]$} & $\begin{array}{c}\text { Plasmablastic plasma } \\
\text { cell } \\
\text { myeloma }\end{array}$ & [179] \\
\hline B & Primary effusion lymphoma (PEL) & Monoclonal & $\begin{array}{c}\text { EBER+/-, } \\
\text { MYC translocation }\end{array}$ & {$[170,171]$} & EBV-negative PEL & {$[170,171]$} \\
\hline $\mathrm{NK} / \mathrm{T}$ & $\begin{array}{l}\text { Aggressive NK-cell } \\
\text { leukemia (ANKL) }\end{array}$ & Monoclonal & $\begin{array}{l}\text { CD2+, surface CD3-, } \\
\text { CD3-epsilon+, CD5-, } \\
\text { CD56+ }\end{array}$ & {$[180,181]$} & $\begin{array}{c}\text { EBV-negative } \\
\text { aggressive NK-cell } \\
\text { leukemia }\end{array}$ & [182] \\
\hline $\mathrm{NK} / \mathrm{T}$ & $\begin{array}{c}\text { Systemic EBV+T-cell lymphoma of } \\
\text { childhood }\end{array}$ & Monoclonal & $\begin{array}{l}\text { CD8+, CD2+, } \\
\text { surface CD3+, TIA1+, } \\
\text { granzyme B+ }\end{array}$ & {$[183,184]$} & $\begin{array}{l}\text { Non EBV-associated } \\
\text { hemophagocytic } \\
\text { syndrome }\end{array}$ & [185] \\
\hline $\mathrm{NK} / \mathrm{T}$ & $\begin{array}{c}\text { Chronic active EBV infection of } \\
\text { T-and NK-cell type, systemic form } \\
\text { (CAEBV) }\end{array}$ & Monoclonal & TIA1+, granzyme B+ & {$[186,187]$} & $\begin{array}{l}\text { Inflammation of } \\
\text { unknown } \\
\text { etiology }\end{array}$ & [188] \\
\hline NK/T & $\begin{array}{c}\text { Hydroa vacciniforme-like } \\
\text { lymphoproliferative disorders } \\
\text { (HVLPD) }\end{array}$ & Monoclonal & $\begin{array}{l}\text { CD3+, CD56- }, \text { TIA1+, } \\
\text { granzyme B+ }\end{array}$ & {$[189,190]$} & Hydroa vacciniforme & [191] \\
\hline $\mathrm{NK} / \mathrm{T}$ & $\begin{array}{l}\text { Severe mosquito bite allergy } \\
\text { (SMBA) }\end{array}$ & Monoclonal & CD3-epsilon+, CD56+ & {$[192,193]$} & Not applicable & \\
\hline $\mathrm{NK} / \mathrm{T}$ & $\begin{array}{c}\text { Extranodal NK/T-cell lymphoma, } \\
\text { nasal type (ENKTL) }\end{array}$ & Monoclonal & $\begin{array}{l}\text { CD3+, CD56+, } \\
\text { GNAQ mutation }\end{array}$ & {$[194,195]$} & $\begin{array}{l}\text { Other NT/T-cell } \\
\text { lymphomas }\end{array}$ & [196] \\
\hline $\mathrm{NK} / \mathrm{T}$ & $\begin{array}{l}\text { Angioimmunoblastic T-cell } \\
\text { lymphoma (AITL) }\end{array}$ & Monoclonal & $\begin{array}{l}\text { EBER - }, \text { EBV + B-cell, } \\
\text { RHOA and TET2 } \\
\text { mutation }\end{array}$ & {$[197,198]$} & $\begin{array}{l}\text { Peripheral T-cell } \\
\text { lymphoma, NOS } \\
\text { (PTCL) }\end{array}$ & [199] \\
\hline $\mathrm{NK} / \mathrm{T}$ & $\begin{array}{l}\text { Follicular T-cell lymphoma } \\
\text { (FTCL) }\end{array}$ & Monoclonal & $\begin{array}{l}\text { EBER-, EBV+ } \\
\text { H/RS-like cells, } \\
\text { ITK-STK fusion }\end{array}$ & [200-202] & $\begin{array}{l}\text { Peripheral T-cell } \\
\text { lymphoma, NOS } \\
\text { (PTCL) }\end{array}$ & [203] \\
\hline $\mathrm{NK} / \mathrm{T}$ & $\begin{array}{l}\text { Nodal peripheral T-cell } \\
\text { lymphoma with T follicular helper } \\
\text { phenotype }\end{array}$ & Monoclonal & $\begin{array}{l}\text { Possibility of tumor cell } \\
\text { rich variants of AITL }\end{array}$ & {$[204,205]$} & $\begin{array}{l}\text { Peripheral T-cell } \\
\text { lymphoma, NOS } \\
\text { (PTCL) }\end{array}$ & [206] \\
\hline Hodgkin & $\begin{array}{l}\text { Classic Hodgkin lymphoma } \\
\text { (CHL) }\end{array}$ & Monoclonal & $\begin{array}{l}\text { CD30+, CD15+, } \\
\text { Mixed cellularity }\end{array}$ & {$[207,208]$} & $\begin{array}{l}\text { Nodular lymphocyte } \\
\text { predominant Hodgkin } \\
\text { lymphoma (NPDHL) }\end{array}$ & [209] \\
\hline $\begin{array}{l}\text { IA- } \\
\text { LPD }\end{array}$ & $\begin{array}{l}\text { Lymphoproliferative diseases } \\
\text { associated with primary immune } \\
\text { disorders (PID) }\end{array}$ & Variable & $\begin{array}{l}\text { Various lesions and } \\
\text { etiologies }\end{array}$ & {$[152,210]$} & Various lesions & [152] \\
\hline $\begin{array}{l}\text { IA- } \\
\text { LPD }\end{array}$ & $\begin{array}{l}\text { Lymphomas associated with HIV } \\
\text { infection }\end{array}$ & Monoclonal & $\begin{array}{l}\text { Various lesions, } \\
\text { including, PEL, } \\
\text { plasmablastic } \\
\text { lymphoma and } \\
\text { HHV8+DLBCL }\end{array}$ & {$[211,212]$} & Not applicable & \\
\hline $\begin{array}{l}\text { IA- } \\
\text { LPD }\end{array}$ & $\begin{array}{c}\text { Post-transplant } \\
\text { lymphoproliferative disorders } \\
\text { (PTLD) }\end{array}$ & Variable & $\mathrm{EBV}+($ most cases $)$ & [152] & EBV-negative PTLD & {$[213,214]$} \\
\hline $\begin{array}{l}\text { IA- } \\
\text { LPD }\end{array}$ & $\begin{array}{c}\text { Other iatrogenic } \\
\text { immunodeficiency-associated } \\
\text { lymphoproliferative disorders } \\
\text { (OI-LPD) }\end{array}$ & Variable & $\begin{array}{l}\text { Immunosuppressive } \\
\text { drugs, including } \\
\text { methotrexate }\end{array}$ & [215] & Various lesions & [152] \\
\hline
\end{tabular}


Nasopharyngeal carcinoma, non-keratinizing type is associated with EBV, which is detected by in situ hybridization for EBER [216]. The typical histology, cancer cell nests intermingled with lymphocytes and plasma cells, is often called lymphoepithelial carcinoma [217]. Nasopharyngeal carcinoma typically shows latency II and, therefore, LMP-driven carcinogenesis [218,219]. In addition, EBV-positive nasopharyngeal carcinoma is accompanied by NF- $\mathrm{KB}$ activation [220]. Other characteristics of EBV-associated malignancies, e.g., nasopharyngeal carcinoma [221], Hodgkin's lymphoma [222], and gastric cancer [223,224], include unique DNA methylation patterns, also called the CpG-island methylator phenotype (CIMP) [225]. These epigenetic changes are induced by DNMT1 upregulation via LMP $[226,227]$.

EBV positivity is an emerging predictive biomarker of gastric cancer. A distinctive histological finding of gastric cancer, lymphoid stroma [228], is a molecular pathological clue of not only microsatellite instability [229] but also EBV positivity [230]. EBV-positive gastric cancer has a better prognosis than that of negative cases. Based on TCGA, the EBV subtype accounts for $9 \%$ of gastric carcinoma cases, and its unique feature is the frequent amplification of PD-L1 and PD-L2 [231]. Therefore, checkpoint inhibitor therapy is expected to be effective for EBV+GC.

EBV-associated smooth muscle tumor $(\mathrm{EBV}+\mathrm{SMT})$ is an intermediate soft tissue neoplasm. Data for this rare entity are lacking in TCGA [232] and PCAWG [29]. The mesenchymal tumor was initially observed in clinical settings in individuals with immunosuppression. Consistent with the initial speculation [233], EBV has been detected in HIV-associated smooth muscle tumors [234]. Now, this mesenchymal tumor has been classified into three etiologies, HIV-associated, post-transplantation, and primary immunodeficient EBV+SMT [235]. The vast majority of primary immunodeficient EBV+SMT cases are pediatric multicentric lesions, whereas patients with secondary immunodeficient $\mathrm{EBV}+\mathrm{SMT}$ are predominantly adults, especially after organ transplant. Rarely, EBV+SMT arises from iatrogenic immunosuppression for autoimmune disease [236]. Promising therapeutic targets are MYC overexpression and AKT/mTOR pathway activation $[237,238]$.

\subsection{Kaposi Sarcoma Herpes Virus (KSHV/HHV-8)}

In 1994, Kaposi sarcoma herpes virus (KSHV), also known as human herpesvirus 8 (HHV-8), was discovered in a case of Kaposi sarcoma [239]. KSHV latently infects Bcells [240,241] and then expands to vascular endothelial cells [242]. The KSHV genome contains genes encoding essential components (i.e., DNA polymerase), as well as homologues, including, Bcl-2, cyclin D1, and interleukin-6 (IL-6). Of note, viral IL-6 enhances proliferation and angiogenesis in Kaposi sarcoma [243].

Latency-associated nuclear antigen-1 (LANA-1), encoded by open reading frame 73 (ORF73), plays an important role in the duplication and stabilization of episomal KSHV [244] in addition to the gain of oncogenic properties [245,246]. In other words, KSHVinfected cells latently proliferate under LANA-1 expression without active virus replication.

Kaposi sarcoma (KS) is a locally aggressive vascular endothelial neoplasia, typically arising in the skin. Clinico-epidemiologically, $\mathrm{KS}$ is classified into four types: classic indolent KS, endemic African KS, AIDS-associated KS, and iatrogenic KS. KSHV is consistently detected in all subtypes, suggesting that the pathogenesis is associated with epidemiological distribution and/or immunosuppression $[247,248]$. Although clinical KS shows a multistage disease process (patch, plaque, and nodular stages), the lesions may show regression [249]. Anti-LANA antibody is used as a diagnostic marker in KS [250]. The standard therapy for KS is currently highly active anti-retroviral therapy with systemic chemotherapy in the advanced stage [251].

KSHV infection also leads to the emergence of KSHV-related hematolymphoid proliferation. These hematopoietic lesions include primary effusion lymphoma (PEL) [170,171], HHV8-positive multicentric Castleman disease (HHV8+MCD) [252], HHV8-positive dif- 
fuse large B-cell lymphoma, NOS (HHV8+DLBCL) [253], and HHV8-positive germinotropic lymphoproliferative disorder (GLPD) [254-256] (Table 5).

Table 5. Association between hematolymphoid lesions and KSHV.

\begin{tabular}{|c|c|c|c|c|c|c|}
\hline $\begin{array}{l}\text { Cell } \\
\text { Linage }\end{array}$ & $\begin{array}{l}\text { Diagnostic Entity } \\
\text { (Abbreviation) }\end{array}$ & Clonality & Common Features & References & $\begin{array}{l}\text { Virus Negative } \\
\text { Mimicry }\end{array}$ & References \\
\hline B & $\begin{array}{l}\text { Primary effusion lymphoma } \\
\text { (PEL) and its solid variants }\end{array}$ & Monoclonal & $\begin{array}{c}\text { CD20-, } \mathrm{HIV}+/- \\
\mathrm{EBV}+/-\end{array}$ & $\begin{array}{l}{[170,171]} \\
{[257,258]}\end{array}$ & $\begin{array}{l}\text { HHV8 negative } \\
\text { common } \\
\text { effusion lymphoma } \\
\text { (HENCEL) }\end{array}$ & [259] \\
\hline B & $\begin{array}{l}\text { HHV8-positive multicentric } \\
\text { Castleman disease } \\
\text { (HHV8+MCD) }\end{array}$ & Polyclonal & $\begin{array}{c}\text { MUM1+, CD138-, } \\
\text { HIV+/-, EBV- }\end{array}$ & [252] & $\begin{array}{l}\text { HHV8-negative } \\
\text { multicentric } \\
\text { Castleman disease } \\
\text { (HHV8-MCD) }\end{array}$ & [260] \\
\hline B & $\begin{array}{l}\text { HHV8-positive diffuse large } \\
\text { B-cell lymphoma, NOS } \\
\text { (HHV8+DLBCL) }\end{array}$ & Monoclonal & $\begin{array}{c}\text { CD20+/-, CD79a-, } \\
\text { CD138-, HIV+/-, } \\
\text { EBV- }\end{array}$ & [253] & $\begin{array}{l}\text { Plasmablastic } \\
\text { lymphoma }\end{array}$ & {$[177,178]$} \\
\hline B & $\begin{array}{c}\text { HHV8-positive } \\
\text { germinotropic } \\
\text { lymphoproliferative } \\
\text { disorder (GLPD) }\end{array}$ & $\begin{array}{l}\text { Polyclonal/ } \\
\text { oligoclonal }\end{array}$ & $\begin{array}{c}\text { MUM1+, CD138-, } \\
\text { HIV-, EBV+ }\end{array}$ & [254-256] & $\begin{array}{l}\text { Plasmablastic } \\
\text { lymphoma }\end{array}$ & {$[177,178]$} \\
\hline
\end{tabular}

Despite the B-cell origin, PEL expresses CD138 but lacks CD19 and CD20, suggesting that this unique terminally differentiated B-cell phenotype is a diagnostic marker for PEL in AIDS-associated lymphomas. Consistent with the findings for KS, PEL and its solid variant $[257,258]$ always express LANA-1. Therefore, HHV8-negative common effusion lymphoma (HENCEL) should be considered a distinct entity [259]. On the other hand, HHV8+MCD is a systemic lymphoproliferative disorder with KSHV-infected Bcells, polyclonal gammaglobulinemia, and a high concentration of serum IL-6 [261]. The majority of cases arise from HHV8+MCD in patients with AIDS [262]. Notably, large B-cell lymphoma often arises in the HHV8+MCD background [253]. The tumor cells show a large plasmablastic morphology with LANA-1 expression, whereas plasmablastic lymphoma, affecting the oral cavity of patients with AIDS, are KSHV-negative [177,178]. Taken together, KSHV-related hematolymphoid lesions can be distinguishable by LANA-1 expression in B-cells. However, the treatment of these lesions is still a big clinical challenge.

\subsection{Merkel Cell Polyoma Virus (MCV)}

MCV was first isolated from Merkel cell carcinoma (MCC) [263] by the digital transcriptome subtraction method [264]. MCV has at least five viral genes, VP1, VP2, VP3, and small and large T antigen (LT). LT is a principal protein in carcinogenesis, as in other polyoma viruses $[265,266]$. LT functions in both $\mathrm{Rb}$ pathway inactivation via the $\mathrm{Rb}$ binding site $[267,268]$ and viral replication by the helicase domain at the C-terminus [269]. However, MCV in MCC harbors frequent nonsense mutations in the LT gene, indicating that mutant MCV fails to replicate due to the lack of the helicase domain. In addition, MCC is associated with MCV integration with the disconnected C-terminal region of LT [270]. These LT modifications are a probable oncogenic event in Merkel cell carcinogenesis. Other recurrent genomic changes in MCC include mutations in TP53, Rb, and PIK3CA [271] and L-myc amplification [272].

MCC has several synonyms, including primary cutaneous neuroendocrine carcinoma, trabecular carcinoma, and Toker tumor [273]; however, its origin remains unclear. Before the virus was isolated, UV damage was identified as a probable cause of MCC because this rare carcinoma typically occurs in sun-damaged skin of elderly individuals. Like other virusrelated tumors, MCC is also associated with immunosuppression [274]. MCC sometimes regresses spontaneously despite its highly aggressive malignant behavior [275]. Elimination may be possible by the anti-tumor immune response, as in malignant melanoma [276] . 
A diagnostic marker of MCC is an anti-LT antibody, CM2B4, generated from exon 2 of the LT gene in MCV [277]. Nevertheless, in a minority of MCC cases, MCV and CM2B4 expression are lacking [278]. Compared with MCV-positive MCC, MCV-negative MCC tends to harbor more frequent driver mutations mentioned above and a greater tumor mutation burden as a result of UV damage [279]. In addition, combined squamous and neuroendocrine carcinoma of the skin is MCV-negative $[277,279]$, suggesting that $\mathrm{MCV}$-negative cutaneous neuroendocrine carcinoma is a pure UV damage-driven cancer, unlike MCV-positive MCC. Another diagnostic clue is a dot-like CK20-expression pattern; however, a CK20-negative form exists [277,280].

Interestingly, tumor infiltrating lymphocytes, predictive biomarkers of immunotherapy [281,282], have recently been identified as a favorable prognostic marker of MCC [283]. Therefore, checkpoint blockade therapy is promising for the treatment of MCC [284].

\subsection{Human T-Cell Leukemia Virus Type 1 (HTLV-1)}

HTLV-1 is a deltaretrovirus that was first isolated in 1980 [285] after initial reports of adult T-cell leukemia/lymphoma (ATLL) in Japan [286]. HTLV-1 infection requires contact between the HTLV-1-infected cell and intact cell because the viral particle has a low infection efficiency [287]. By reverse transcriptase [288], HTLV-1 proviral DNA is randomly integrated into the host genome [289]. For the detection of HTLV-1, an anti-ATLL antibody (ATLA) is used owing to the scarcity of the viral particles in human sera [290]. HTLV1 induces not only ATLL but also various HTLV-1-associated reactive lesions, including HTLV-1-associated myelopathy (HAM) [291] and HTLV-1-associated uveitis [292].

In HTLV-1-related carcinogenesis, Tax and HTLV-1 bZIP factor (HBZ) are cardinal oncogenes. The transactivator Tax induces viral replication and immortalization of human T-cells $[293,294]$. However, the function of Tax in ATLL is frequently suppressed by genetic and epigenetic alterations [295,296], suggesting that this gene is unnecessary in the later phase of the malignant process. In contrast, $\mathrm{HBZ}$ is essential for the malignant process of ATLL [297-299]. Interestingly, HBZ not only represses HTLV-1 transcription by CREB2 inactivation [300] but also counteracts Tax [301-303], suggesting that the abovementioned Tax suppression can promote HBZ-mediated signaling.

ATLL is a CD4+ T-cell malignancy, whose atypical lymphocytes are called flower cells [304]. ATLL tissues typically express CD2, CD3, CD4, CD25, and HLA-DR, and this immunophenotype resembles that of helper/inducer T-cells. In addition, ATLL tissues frequently express a regulatory T-cell marker, FOXP3 [305]. The age of onset of ATLL is nearly 60 years, and it is classified into four clinical types, smoldering, chronic, lymphoma, and acute types [306]. The poor prognosis of ATLL, especially acute and lymphoma types, can be explained by the treatment-refractory phenotype and opportunistic infections.

CC chemokine receptor 4 (CCR4), also known as K5-5 [307], CMKBR4 [308], or CD194 [309], is a therapeutic target for HTLV-1-related diseases [310]. CCR4 expression is specific to Th2 [311] (CD4+ CCR4+) and Treg [309] (CD4+ CD25+) cells. Consistent with its counterpart, CCR4 is frequently expressed in ATLL [312,313]. Interestingly, a genomic analysis revealed that one-third of ATLL cases involve CCR4 mutations [314]. These mutations increase CCR4 expression $[315,316]$ and may have predictive value for the response to the anti-CCR4 therapeutic agent mogamulizumab [317]. Anti-CCR4 immunotherapy is a promising treatment for HAM [318].

\subsection{Additional Tumor Viruses}

Because MCV was first identified in 2008, there is still room for improving our understanding of tumor viruses. For example, we describe three novel candidate tumor viruses, human cytomegalovirus (CMV/HHV-5), human herpesvirus-6 (HHV-6) and adeno-associated virus-2 (AAV-2). 


\subsubsection{Human Cytomegalovirus (CMV/HHV-5)}

The largest human herpesvirus, CMV/HHV-5, was firstly isolated in 1957 from an infant with cytomegalic inclusion disease [319], following the isolation of mouse cytomegalovirus (also called as salivary gland virus) in 1954 [320]. The owl's eye appearance of inclusion bodies is a well-established histological clue of CMV infected cells [321]. Like other herpesviruses, CMV latently infects most individuals during childhood. However, the viral proliferation causes organopathy in immunodeficient individuals, including fetuses or immunocompromised hosts such as post-transplant and AIDS patients [322,323]. To prevent the life-threatening disease, detection of CMV antigenemia using with the tegument protein pp65 (UL83) [324,325] and prophylactic and preemptive therapy [326] are performed in clinical setting.

Although latent CMV infection itself is believed to be asymptomatic and harmless under normal immune status, its enigmatic oncogenic functions in breast cancer have been attracting attention [327]. "Oncomodulation", proposed by Michaelis et al. [328], is defined as enhanced malignant progression of tumor cells through CMV infection. Like survival in the infected normal cells, CMV products affect various tumor cell properties, cell cycle, apoptosis, metastasis, angiogenesis, and immune evasion. In addition, a specific CMV strain has been reported to transform human mammary epithelial cells into triplenegative breast cancer-like cells [329]. Consistent with these findings, the IARC advisory board group recently recommended CMV as a high priority agent to be evaluated for its carcinogenicity [12].

\subsubsection{Human Herpesvirus-6 (HHV-6)}

HHV-6 was initially named human B-lymphotropic virus [330] but was subsequently identified as a herpesvirus [331]. HHV-6 consists of two distinctive variants, HHV-6A and HHV-6B, based on biological, clinical and epidemiological differences, despite the overall highly conserved genetic sequences [332,333]. The latter is a cause of exanthema subitem [331] and HHV-6B encephalitis [334] whereas the former still remains unclear with respect to initial clinical symptoms. Except for infants, almost all individuals have latent HHV-6 infection [335,336]. HHV-6 latently infects bone marrow progenitor cells [337] and is integrated into the human genome [338]. Notably, this integration includes the whole genome of HHV-6 and also occurs in germ cells [339,340]. Similarly, tumor tissues sometimes contain HHV-6, although a direct oncogenic effect of HHV-6 has not yet been demonstrated [341]. However, accumulating evidence suggests that an HHV-6 viral protein, direct repeat 7 (DR7), may function as an oncoprotein through the p53 downregulation in EBV-negative lymphoma and glioma [342-344]. To clarify the molecular significance of HHV-6, further investigations are needed.

\subsubsection{Adeno-Associated Virus-2 (AAV-2)}

$\mathrm{AAV}$ is a minute parvovirus, discovered as a small particle in the preparation of adenovirus [345,346]. Owing to the unique biological properties of AAV-2 [347], AAV is utilized as a gene therapy vehicle [348]. Currently, retroviruses and AAV-2 are potent vectors to induce external gene expression. Although retroviruses enable persistent gene expression by genomic integration of the viral sequence, the alteration can lead to insertional mutagenesis [349-351]. In contrast, AAV-2 is believed to be safe owing to its extremely low integration rate, except in a single fatal clinical report [352]. However, a long-term observational study revealed that AAV-treated mice harbor neoplastic cells in the liver $[353,354]$. The AAV sequence fragment has been detected in HCC, like HBV-related mutagenesis [355]. AAV administration results in the induction of hepatic proliferative lesions in dogs [356]. However, contrary results have been reported [357,358]. In fact, the liver is one of most frequent AAV detection sites in humans [359]. Taken together, the relationship between AAV and hepatocellular carcinogenesis is still controversial.

Further studies of these novel tumor virus candidates are required. 


\section{Conclusions}

In this review we described the current understanding of virus-driven carcinogenesis. Tumor viruses were overlooked for a long time, because of their invisibility and long latency. However, their oncogenic activities have been detected by our technologies. Furthermore, the nature of novel tumor virus candidates, including CMV, HHV-6, and AAV2 , is becoming unraveled. To win the war against virus-associated cancer, comprehensive approaches for cancer prevention, diagnosis, and treatment are necessary in the future.

Author Contributions: Conceptualization, Y.H.; writing—original draft preparation, Y.H.; writingreview and editing, T.I., A.H. (Akihiro Hirata) and K.H.; visualization, Y.H.; supervision, H.T., H.O., M.S., T.T. and A.H. (Akira Hara). All authors have read and agreed to the published version of the manuscript.

Funding: This research received no external funding.

Conflicts of Interest: The authors declare no conflict of interest.

\section{References}

1. Hatano, Y.; Hatano, K.; Tamada, M.; Morishige, K.I.; Tomita, H.; Yanai, H.; Hara, A. A Comprehensive Review of Ovarian Serous Carcinoma. Adv. Anat. Pathol. 2019, 26, 329-339. [CrossRef]

2. Hatano, Y.; Tamada, M.; Matsuo, M.; Hara, A. Molecular Trajectory of BRCA1 and BRCA2 Mutations. Front. Oncol. 2020, 10, 361. [CrossRef] [PubMed]

3. Martin, G.S. The road to Src. Oncogene 2004, 23, 7910-7917. [CrossRef] [PubMed]

4. Woolhouse, M.; Scott, F.; Hudson, Z.; Howey, R.; Chase-Topping, M. Human viruses: Discovery and emergence. Philos. Trans. $R$ Soc. Lond. B Biol. Sci. 2012, 367, 2864-2871. [CrossRef] [PubMed]

5. Adams, M.J.; Lefkowitz, E.J.; King, A.M.; Harrach, B.; Harrison, R.L.; Knowles, N.J.; Kropinski, A.M.; Krupovic, M.; Kuhn, J.H.; Mushegian, A.R.; et al. 50 years of the International Committee on Taxonomy of Viruses: Progress and prospects. Arch. Virol. 2017, 162, 1441-1446. [CrossRef] [PubMed]

6. Parkin, D.M. The global health burden of infection-associated cancers in the year 2002. Int. J. Cancer 2006, 118, 3030-3044. [CrossRef]

7. De Martel, C.; Ferlay, J.; Franceschi, S.; Vignat, J.; Bray, F.; Forman, D.; Plummer, M. Global burden of cancers attributable to infections in 2008: A review and synthetic analysis. Lancet Oncol. 2012, 13, 607-615. [CrossRef]

8. Plummer, M.; de Martel, C.; Vignat, J.; Ferlay, J.; Bray, F.; Franceschi, S. Global burden of cancers attributable to infections in 2012: A synthetic analysis. Lancet Glob. Health 2016, 4, e609-e616. [CrossRef]

9. De Martel, C.; Georges, D.; Bray, F.; Ferlay, J.; Clifford, G.M. Global burden of cancer attributable to infections in 2018: A worldwide incidence analysis. Lancet Glob. Health 2020, 8, e180-e190. [CrossRef]

10. Bouvard, V.; Baan, R.; Straif, K.; Grosse, Y.; Secretan, B.; El Ghissassi, F.; Benbrahim-Tallaa, L.; Guha, N.; Freeman, C.; Galichet, L.; et al. A review of human carcinogens-Part B: Biological agents. Lancet Oncol. 2009, 10, 321-322. [CrossRef]

11. Bouvard, V.; Baan, R.A.; Grosse, Y.; Lauby-Secretan, B.; El Ghissassi, F.; Benbrahim-Tallaa, L.; Guha, N.; Straif, K. Carcinogenicity of malaria and of some polyomaviruses. Lancet Oncol. 2012, 13, 339-340. [CrossRef]

12. Marques, M.M.; Berrington de Gonzalez, A.; Beland, F.A.; Browne, P.; Demers, P.A.; Lachenmeier, D.W.; Bahadori, T.; Barupal, D.K.; Belpoggi, F.; Comba, P.; et al. Advisory Group recommendations on priorities for the IARC Monographs. Lancet Oncol. 2019, 20, 763-764. [CrossRef]

13. Baltimore, D. Expression of animal virus genomes. Bacteriol. Rev. 1971, 35, 235-241. [CrossRef]

14. Berman, J.J. Viruses. In Taxonomic Guide to Infectious Diseases, 2nd ed.; Academic Press: Cambridge, MA, USA, 2019; pp. 263-319. [CrossRef]

15. Zur Hausen, H. Oncogenic DNA viruses. Oncogene 2001, 20, 7820-7823. [CrossRef] [PubMed]

16. Hanahan, D.; Weinberg, R.A. The hallmarks of cancer. Cell 2000, 100, 57-70. [CrossRef]

17. Hanahan, D.; Weinberg, R.A. Hallmarks of cancer: The next generation. Cell 2011, 144, 646-674. [CrossRef] [PubMed]

18. Mesri, E.A.; Feitelson, M.A.; Munger, K. Human viral oncogenesis: A cancer hallmarks analysis. Cell Host Microbe 2014, 15, 266-282. [CrossRef]

19. Virgin, H.W.; Wherry, E.J.; Ahmed, R. Redefining chronic viral infection. Cell 2009, 138, 30-50. [CrossRef] [PubMed]

20. Chen, X.; Kost, J.; Sulovari, A.; Wong, N.; Liang, W.S.; Cao, J.; Li, D. A virome-wide clonal integration analysis platform for discovering cancer viral etiology. Genome Res. 2019, 29, 819-830. [CrossRef]

21. Beachy, P.A.; Karhadkar, S.S.; Berman, D.M. Tissue repair and stem cell renewal in carcinogenesis. Nature 2004, 432, 324-331. [CrossRef]

22. Hatano, Y.; Fukuda, S.; Hisamatsu, K.; Hirata, A.; Hara, A.; Tomita, H. Multifaceted Interpretation of Colon Cancer Stem Cells. Int. J. Mol. Sci. 2017, 18. [CrossRef] [PubMed] 
23. Knijnenburg, T.A.; Wang, L.; Zimmermann, M.T.; Chambwe, N.; Gao, G.F.; Cherniack, A.D.; Fan, H.; Shen, H.; Way, G.P.; Greene, C.S.; et al. Genomic and Molecular Landscape of DNA Damage Repair Deficiency across The Cancer Genome Atlas. Cell Rep. 2018, 23, 239-254.e6. [CrossRef]

24. Alexandrov, L.B.; Kim, J.; Haradhvala, N.J.; Huang, M.N.; Tian Ng, A.W.; Wu, Y.; Boot, A.; Covington, K.R.; Gordenin, D.A.; Bergstrom, E.N.; et al. The repertoire of mutational signatures in human cancer. Nature 2020, 578, 94-101. [CrossRef]

25. Mortaz, E.; Tabarsi, P.; Mansouri, D.; Khosravi, A.; Garssen, J.; Velayati, A.; Adcock, I.M. Cancers Related to Immunodeficiencies: Update and Perspectives. Front. Immunol. 2016, 7, 365. [CrossRef]

26. Barre-Sinoussi, F.; Chermann, J.C.; Rey, F.; Nugeyre, M.T.; Chamaret, S.; Gruest, J.; Dauguet, C.; Axler-Blin, C.; Vezinet-Brun, F.; Rouzioux, C.; et al. Isolation of a T-lymphotropic retrovirus from a patient at risk for acquired immune deficiency syndrome (AIDS). Science 1983, 220, 868-871. [CrossRef]

27. Ghosn, J.; Taiwo, B.; Seedat, S.; Autran, B.; Katlama, C. Hiv. Lancet 2018, 392, 685-697. [CrossRef]

28. Engels, E.A. Epidemiologic perspectives on immunosuppressed populations and the immunosurveillance and immunocontainment of cancer. Am. J. Transplant. 2019, 19, 3223-3232. [CrossRef] [PubMed]

29. Zapatka, M.; Borozan, I.; Brewer, D.S.; Iskar, M.; Grundhoff, A.; Alawi, M.; Desai, N.; Sultmann, H.; Moch, H.; Pathogens, P.; et al. The landscape of viral associations in human cancers. Nat. Genet. 2020, 52, 320-330. [CrossRef]

30. Ferreira, D.A.; Tayyar, Y.; Idris, A.; McMillan, N.A.J. A “hit-and-run” affair-A possible link for cancer progression in virally driven cancers. Biochim. Biophys. Acta Rev. Cancer 2021, 1875, 188476. [CrossRef] [PubMed]

31. Khoury, J.D.; Tannir, N.M.; Williams, M.D.; Chen, Y.; Yao, H.; Zhang, J.; Thompson, E.J.; Network, T.; Meric-Bernstam, F.; Medeiros, L.J.; et al. Landscape of DNA virus associations across human malignant cancers: Analysis of 3775 cases using RNA-Seq. J. Virol. 2013, 87, 8916-8926. [CrossRef] [PubMed]

32. Cantalupo, P.G.; Katz, J.P.; Pipas, J.M. Viral sequences in human cancer. Virology 2018, 513, 208-216. [CrossRef]

33. Smith, C.C.; Beckermann, K.E.; Bortone, D.S.; De Cubas, A.A.; Bixby, L.M.; Lee, S.J.; Panda, A.; Ganesan, S.; Bhanot, G.; Wallen, E.M.; et al. Endogenous retroviral signatures predict immunotherapy response in clear cell renal cell carcinoma. J. Clin. Investig. 2018, 128, 4804-4820. [CrossRef]

34. Orth, G.; Favre, M.; Croissant, O. Characterization of a new type of human papillomavirus that causes skin warts. J. Virol. 1977, 24, 108-120. [CrossRef]

35. Durst, M.; Gissmann, L.; Ikenberg, H.; zur Hausen, H. A papillomavirus DNA from a cervical carcinoma and its prevalence in cancer biopsy samples from different geographic regions. Proc. Natl. Acad. Sci. USA 1983, 80, 3812-3815. [CrossRef]

36. de Villiers, E.M.; Fauquet, C.; Broker, T.R.; Bernard, H.U.; zur Hausen, H. Classification of papillomaviruses. Virology 2004, 324, 17-27. [CrossRef]

37. Grce, M.; Husnjak, K.; Skerlev, M.; Lipozencic, J.; Pavelic, K. Detection and typing of human papillomaviruses by means of polymerase chain reaction and fragment length polymorphism in male genital lesions. Anticancer Res. 2000, 20, $2097-2102$. [PubMed]

38. Betz, S.J. HPV-Related Papillary Lesions of the Oral Mucosa: A Review. Head Neck Pathol. 2019, 13, 80-90. [CrossRef] [PubMed]

39. Cogliano, V.; Baan, R.; Straif, K.; Grosse, Y.; Secretan, B.; Ghissassi, F.E. Carcinogenicity of human papillomaviruses. Lancet Oncol. 2005, 6. [CrossRef]

40. Werness, B.A.; Levine, A.J.; Howley, P.M. Association of human papillomavirus types 16 and 18 E6 proteins with p53. Science 1990, 248, 76-79. [CrossRef] [PubMed]

41. Scheffner, M.; Werness, B.A.; Huibregtse, J.M.; Levine, A.J.; Howley, P.M. The E6 oncoprotein encoded by human papillomavirus types 16 and 18 promotes the degradation of p53. Cell 1990, 63, 1129-1136. [CrossRef]

42. Trave, G.; Zanier, K. HPV-mediated inactivation of tumor suppressor p53. Cell Cycle 2016, 15, 2231-2232. [CrossRef]

43. Dyson, N.; Howley, P.M.; Munger, K.; Harlow, E. The human papilloma virus-16 E7 oncoprotein is able to bind to the retinoblastoma gene product. Science 1989, 243, 934-937. [CrossRef] [PubMed]

44. Darnell, G.A.; Schroder, W.A.; Antalis, T.M.; Lambley, E.; Major, L.; Gardner, J.; Birrell, G.; Cid-Arregui, A.; Suhrbier, A. Human papillomavirus E7 requires the protease calpain to degrade the retinoblastoma protein. J. Biol. Chem. 2007, 282, 37492-37500. [CrossRef] [PubMed]

45. Ronco, L.V.; Karpova, A.Y.; Vidal, M.; Howley, P.M. Human papillomavirus 16 E6 oncoprotein binds to interferon regulatory factor-3 and inhibits its transcriptional activity. Genes Dev. 1998, 12, 2061-2072. [CrossRef]

46. Li, S.; Labrecque, S.; Gauzzi, M.C.; Cuddihy, A.R.; Wong, A.H.; Pellegrini, S.; Matlashewski, G.J.; Koromilas, A.E. The human papilloma virus (HPV)-18 E6 oncoprotein physically associates with Tyk2 and impairs Jak-STAT activation by interferon-alpha. Oncogene 1999, 18, 5727-5737. [CrossRef] [PubMed]

47. Barnard, P.; Payne, E.; McMillan, N.A. The human papillomavirus E7 protein is able to inhibit the antiviral and anti-growth functions of interferon-alpha. Virology 2000, 277, 411-419. [CrossRef]

48. Park, J.S.; Kim, E.J.; Kwon, H.J.; Hwang, E.S.; Namkoong, S.E.; Um, S.J. Inactivation of interferon regulatory factor-1 tumor suppressor protein by HPV E7 oncoprotein. Implication for the E7-mediated immune evasion mechanism in cervical carcinogenesis. J. Biol. Chem. 2000, 275, 6764-6769. [CrossRef] [PubMed]

49. Pett, M.; Coleman, N. Integration of high-risk human papillomavirus: A key event in cervical carcinogenesis? J. Pathol. 2007, 212, 356-367. [CrossRef] [PubMed] 
50. Thorland, E.C.; Myers, S.L.; Persing, D.H.; Sarkar, G.; McGovern, R.M.; Gostout, B.S.; Smith, D.I. Human papillomavirus type 16 integrations in cervical tumors frequently occur in common fragile sites. Cancer Res. 2000, 60, 5916-5921.

51. Hu, Z.; Zhu, D.; Wang, W.; Li, W.; Jia, W.; Zeng, X.; Ding, W.; Yu, L.; Wang, X.; Wang, L.; et al. Genome-wide profiling of HPV integration in cervical cancer identifies clustered genomic hot spots and a potential microhomology-mediated integration mechanism. Nat. Genet. 2015, 47, 158-163. [CrossRef]

52. Lawson, A.R.; Hindley, G.F.; Forshew, T.; Tatevossian, R.G.; Jamie, G.A.; Kelly, G.P.; Neale, G.A.; Ma, J.; Jones, T.A.; Ellison, D.W.; et al. RAF gene fusion breakpoints in pediatric brain tumors are characterized by significant enrichment of sequence microhomology. Genome Res. 2011, 21, 505-514. [CrossRef]

53. Santacroce, L.; Di Cosola, M.; Bottalico, L.; Topi, S.; Charitos, I.A.; Ballini, A.; Inchingolo, F.; Cazzolla, A.P.; Dipalma, G. Focus on HPV Infection and the Molecular Mechanisms of Oral Carcinogenesis. Viruses 2021, 13, 559. [CrossRef]

54. Daling, J.R.; Madeleine, M.M.; Johnson, L.G.; Schwartz, S.M.; Shera, K.A.; Wurscher, M.A.; Carter, J.J.; Porter, P.L.; Galloway, D.A.; McDougall, J.K. Human papillomavirus, smoking, and sexual practices in the etiology of anal cancer. Cancer 2004, 101, 270-280. [CrossRef] [PubMed]

55. Alemany, L.; Saunier, M.; Tinoco, L.; Quiros, B.; Alvarado-Cabrero, I.; Alejo, M.; Joura, E.A.; Maldonado, P.; Klaustermeier, J.; Salmeron, J.; et al. Large contribution of human papillomavirus in vaginal neoplastic lesions: A worldwide study in 597 samples. Eur. J. Cancer 2014, 50, 2846-2854. [CrossRef] [PubMed]

56. Bornstein, J.; Bogliatto, F.; Haefner, H.K.; Stockdale, C.K.; Preti, M.; Bohl, T.G.; Reutter, J.; ISSVD Terminology Committee. The 2015 International Society for the Study of Vulvovaginal Disease (ISSVD) Terminology of Vulvar Squamous Intraepithelial Lesions. Obstet. Gynecol. 2016, 127, 264-268. [CrossRef] [PubMed]

57. Anic, G.M.; Giuliano, A.R. Genital HPV infection and related lesions in men. Prev. Med. 2011, 53 (Suppl. S1), S36-S41. [CrossRef]

58. Arafah, M.; Rashid, S.; Tulbah, A.; Akhtar, M. Carcinomas of the Uterine Cervix: Comprehensive Review With An Update on Pathogenesis, Nomenclature of Precursor and Invasive Lesions, and Differential Diagnostic Considerations. Adv. Anat. Pathol. 2021, 28, 150-170. [CrossRef] [PubMed]

59. Syrjanen, S. The role of human papillomavirus infection in head and neck cancers. Ann. Oncol. 2010, 21 (Suppl. S7), vii243-vii245. [CrossRef]

60. Sung, H.; Ferlay, J.; Siegel, R.L.; Laversanne, M.; Soerjomataram, I.; Jemal, A.; Bray, F. Global cancer statistics 2020: GLOBOCAN estimates of incidence and mortality worldwide for 36 cancers in 185 countries. CA Cancer J. Clin. 2021. [CrossRef] [PubMed]

61. Cancer Genome Atlas Research Network. Integrated genomic and molecular characterization of cervical cancer. Nature 2017, 543, 378-384. [CrossRef] [PubMed]

62. Alexandrov, L.B.; Nik-Zainal, S.; Wedge, D.C.; Aparicio, S.A.; Behjati, S.; Biankin, A.V.; Bignell, G.R.; Bolli, N.; Borg, A.; Borresen-Dale, A.L.; et al. Signatures of mutational processes in human cancer. Nature 2013, 500, 415-421. [CrossRef]

63. Henderson, S.; Chakravarthy, A.; Su, X.; Boshoff, C.; Fenton, T.R. APOBEC-mediated cytosine deamination links PIK3CA helical domain mutations to human papillomavirus-driven tumor development. Cell Rep. 2014, 7, 1833-1841. [CrossRef]

64. Ojesina, A.I.; Lichtenstein, L.; Freeman, S.S.; Pedamallu, C.S.; Imaz-Rosshandler, I.; Pugh, T.J.; Cherniack, A.D.; Ambrogio, L.; Cibulskis, K.; Bertelsen, B.; et al. Landscape of genomic alterations in cervical carcinomas. Nature 2014, 506, 371-375. [CrossRef]

65. Female Genital Tumors, 5th ed.; WHO Classification of Tumours Editorial Board: Lyon, France, 2020; Volume 4.

66. Stolnicu, S.; Barsan, I.; Hoang, L.; Patel, P.; Terinte, C.; Pesci, A.; Aviel-Ronen, S.; Kiyokawa, T.; Alvarado-Cabrero, I.; Pike, M.C.; et al. International Endocervical Adenocarcinoma Criteria and Classification (IECC): A New Pathogenetic Classification for Invasive Adenocarcinomas of the Endocervix. Am. J. Surg. Pathol. 2018, 42, 214-226. [CrossRef] [PubMed]

67. Hodgson, A.; Park, K.J.; Djordjevic, B.; Howitt, B.E.; Nucci, M.R.; Oliva, E.; Stolnicu, S.; Xu, B.; Soslow, R.A.; Parra-Herran, C. International Endocervical Adenocarcinoma Criteria and Classification: Validation and Interobserver Reproducibility. Am. J. Surg. Pathol. 2019, 43, 75-83. [CrossRef] [PubMed]

68. Nicolas, I.; Marimon, L.; Barnadas, E.; Saco, A.; Rodriguez-Carunchio, L.; Fuste, P.; Marti, C.; Rodriguez-Trujillo, A.; Torne, A.; Del Pino, M.; et al. HPV-negative tumors of the uterine cervix. Mod. Pathol. 2019, 32, 1189-1196. [CrossRef]

69. Rodriguez-Carunchio, L.; Soveral, I.; Steenbergen, R.D.; Torne, A.; Martinez, S.; Fuste, P.; Pahisa, J.; Marimon, L.; Ordi, J.; del Pino, M. HPV-negative carcinoma of the uterine cervix: A distinct type of cervical cancer with poor prognosis. BJOG 2015, 122, 119-127. [CrossRef]

70. Masumoto, N.; Fujii, T.; Ishikawa, M.; Saito, M.; Iwata, T.; Fukuchi, T.; Susumu, N.; Mukai, M.; Kubushiro, K.; Tsukazaki, K.; et al. P16ink4a overexpression and human papillomavirus infection in small cell carcinoma of the uterine cervix. Hum. Pathol. 2003, 34, 778-783. [CrossRef]

71. Klaes, R.; Friedrich, T.; Spitkovsky, D.; Ridder, R.; Rudy, W.; Petry, U.; Dallenbach-Hellweg, G.; Schmidt, D.; von Knebel Doeberitz, M. Overexpression of p16(INK4A) as a specific marker for dysplastic and neoplastic epithelial cells of the cervix uteri. Int. J. Cancer 2001, 92, 276-284. [CrossRef] [PubMed]

72. World Health Organization. Global Strategy to Accelerate the Elimination of Cervical Cancer as a Public Health Problem; WHO: Geneva, Switzerland, 2020.

73. Gissmann, L.; Wolnik, L.; Ikenberg, H.; Koldovsky, U.; Schnurch, H.G.; zur Hausen, H. Human papillomavirus types 6 and 11 DNA sequences in genital and laryngeal papillomas and in some cervical cancers. Proc. Natl. Acad. Sci. USA 1983, 80, 560-563. [CrossRef] [PubMed] 
74. Schwartz, S.M.; Daling, J.R.; Doody, D.R.; Wipf, G.C.; Carter, J.J.; Madeleine, M.M.; Mao, E.J.; Fitzgibbons, E.D.; Huang, S.; Beckmann, A.M.; et al. Oral cancer risk in relation to sexual history and evidence of human papillomavirus infection. J. Natl. Cancer Inst. 1998, 90, 1626-1636. [CrossRef]

75. Cancer Genome Atlas Network. Comprehensive genomic characterization of head and neck squamous cell carcinomas. Nature 2015, 517, 576-582. [CrossRef] [PubMed]

76. Chernock, R.D.; El-Mofty, S.K.; Thorstad, W.L.; Parvin, C.A.; Lewis, J.S., Jr. HPV-related nonkeratinizing squamous cell carcinoma of the oropharynx: Utility of microscopic features in predicting patient outcome. Head Neck Pathol. 2009, 3, 186-194. [CrossRef] [PubMed]

77. Applebaum, K.M.; Furniss, C.S.; Zeka, A.; Posner, M.R.; Smith, J.F.; Bryan, J.; Eisen, E.A.; Peters, E.S.; McClean, M.D.; Kelsey, K.T. Lack of association of alcohol and tobacco with HPV16-associated head and neck cancer. J. Natl. Cancer Inst. 2007, 99, 1801-1810. [CrossRef] [PubMed]

78. Oganesyan, G.; Saha, S.K.; Guo, B.; He, J.Q.; Shahangian, A.; Zarnegar, B.; Perry, A.; Cheng, G. Critical role of TRAF3 in the Toll-like receptor-dependent and -independent antiviral response. Nature 2006, 439, 208-211. [CrossRef] [PubMed]

79. Cancer Genome Atlas Research Network. Comprehensive genomic characterization of squamous cell lung cancers. Nature 2012, 489, 519-525. [CrossRef] [PubMed]

80. Deng, J.; Chen, H.; Zhou, D.; Zhang, J.; Chen, Y.; Liu, Q.; Ai, D.; Zhu, H.; Chu, L.; Ren, W.; et al. Comparative genomic analysis of esophageal squamous cell carcinoma between Asian and Caucasian patient populations. Nat. Commun. 2017, 8, 1533. [CrossRef] [PubMed]

81. Cancer Genome Atlas Research Network. Integrated genomic characterization of oesophageal carcinoma. Nature 2017, 541, 169-175. [CrossRef]

82. Zhu, X.; Jamshed, S.; Zou, J.; Azar, A.; Meng, X.; Bathini, V.; Dresser, K.; Strock, C.; Yalamarti, B.; Yang, M.; et al. Molecular and immunophenotypic characterization of anal squamous cell carcinoma reveals distinct clinicopathologic groups associated with HPV and TP53 mutation status. Mod. Pathol. 2021, 34, 1017-1030. [CrossRef]

83. Shin, D.M.; Kim, J.; Ro, J.Y.; Hittelman, J.; Roth, J.A.; Hong, W.K.; Hittelman, W.N. Activation of p53 gene expression in premalignant lesions during head and neck tumorigenesis. Cancer Res. 1994, 54, 321-326.

84. Volant, A.; Nousbaum, J.B.; Giroux, M.A.; Roue-Quintin, I.; Metges, J.P.; Ferec, C.; Gouerou, H.; Robaszkiewicz, M. p53 protein accumulation in oesophageal squamous cell carcinomas and precancerous lesions. J. Clin. Pathol. 1995, 48, 531-534. [CrossRef]

85. Kagie, M.J.; Kenter, G.G.; Tollenaar, R.A.; Hermans, J.; Trimbos, J.P.; Fleuren, G.J. p53 protein overexpression, a frequent observation in squamous cell carcinoma of the vulva and in various synchronous vulvar epithelia, has no value as a prognostic parameter. Int. J. Gynecol. Pathol. 1997, 16, 124-130. [CrossRef]

86. McCluggage, W.G. Premalignant lesions of the lower female genital tract: Cervix, vagina and vulva. Pathology 2013, 45, 214-228. [CrossRef]

87. Global Burden of Disease Liver Cancer Collaboration. The Burden of Primary Liver Cancer and Underlying Etiologies From 1990 to 2015 at the Global, Regional, and National Level: Results From the Global Burden of Disease Study 2015. JAMA Oncol. 2017, 3, 1683-1691. [CrossRef] [PubMed]

88. Lam, L.; Fontaine, H.; Bourliere, M.; Lusivika-Nzinga, C.; Dorival, C.; Thabut, D.; Zoulim, F.; Habersetzer, F.; Asselah, T.; Duclos-Vallee, J.C.; et al. Predictive Factors for Hepatocellular Carcinoma in Chronic Hepatitis B Using Structural Equation Modeling: A Prospective Cohort Study. Clin. Res. Hepatol. Gastroenterol. 2021, 101713. [CrossRef] [PubMed]

89. Beste, L.A.; Green, P.; Berry, K.; Belperio, P.; Ioannou, G.N. Hepatitis C-Related Hepatocellular Carcinoma Incidence in the Veterans Health Administration After Introduction of Direct-Acting Antivirals. JAMA 2020, 324, 1003-1005. [CrossRef]

90. Blumberg, B.S.; Alter, H.J.; Visnich, S. A “New” Antigen in Leukemia Sera. JAMA 1965, 191, 541-546. [CrossRef]

91. Dane, D.S.; Cameron, C.H.; Briggs, M. Virus-like particles in serum of patients with Australia-antigen-associated hepatitis. Lancet 1970, 1, 695-698. [CrossRef]

92. Galibert, F.; Mandart, E.; Fitoussi, F.; Tiollais, P.; Charnay, P. Nucleotide sequence of the hepatitis B virus genome (subtype ayw) cloned in E. coli. Nature 1979, 281, 646-650. [CrossRef] [PubMed]

93. Tatematsu, K.; Tanaka, Y.; Kurbanov, F.; Sugauchi, F.; Mano, S.; Maeshiro, T.; Nakayoshi, T.; Wakuta, M.; Miyakawa, Y.; Mizokami, M. A genetic variant of hepatitis B virus divergent from known human and ape genotypes isolated from a Japanese patient and provisionally assigned to new genotype J. J. Virol. 2009, 83, 10538-10547. [CrossRef] [PubMed]

94. Ozasa, A.; Tanaka, Y.; Orito, E.; Sugiyama, M.; Kang, J.H.; Hige, S.; Kuramitsu, T.; Suzuki, K.; Tanaka, E.; Okada, S.; et al. Influence of genotypes and precore mutations on fulminant or chronic outcome of acute hepatitis B virus infection. Hepatology 2006, 44, 326-334. [CrossRef] [PubMed]

95. Orito, E.; Mizokami, M.; Ina, Y.; Moriyama, E.N.; Kameshima, N.; Yamamoto, M.; Gojobori, T. Host-independent evolution and a genetic classification of the hepadnavirus family based on nucleotide sequences. Proc. Natl. Acad. Sci. USA 1989, 86, 7059-7062. [CrossRef]

96. Jiang, Z.; Jhunjhunwala, S.; Liu, J.; Haverty, P.M.; Kennemer, M.I.; Guan, Y.; Lee, W.; Carnevali, P.; Stinson, J.; Johnson, S.; et al. The effects of hepatitis B virus integration into the genomes of hepatocellular carcinoma patients. Genome Res. 2012, $22,593-601$. [CrossRef]

97. Sung, W.K.; Zheng, H.; Li, S.; Chen, R.; Liu, X.; Li, Y.; Lee, N.P.; Lee, W.H.; Ariyaratne, P.N.; Tennakoon, C.; et al. Genome-wide survey of recurrent HBV integration in hepatocellular carcinoma. Nat. Genet. 2012, 44, 765-769. [CrossRef] 
98. McAleer, W.J.; Buynak, E.B.; Maigetter, R.Z.; Wampler, D.E.; Miller, W.J.; Hilleman, M.R. Human hepatitis B vaccine from recombinant yeast. Nature 1984, 307, 178-180. [CrossRef]

99. Sarin, S.K.; Kumar, M.; Lau, G.K.; Abbas, Z.; Chan, H.L.; Chen, C.J.; Chen, D.S.; Chen, H.L.; Chen, P.J.; Chien, R.N.; et al. Asian-Pacific clinical practice guidelines on the management of hepatitis B: A 2015 update. Hepatol. Int. 2016, 10, 1-98. [CrossRef]

100. European Association for the Study of the Liver. EASL 2017 Clinical Practice Guidelines on the management of hepatitis B virus infection. J. Hepatol. 2017, 67, 370-398. [CrossRef] [PubMed]

101. Digestive System Tumors, 5th ed.; WHO Classification of Tumours Editorial Board: Lyon, France, 2019 ; Volume 1.

102. Totoki, Y.; Tatsuno, K.; Covington, K.R.; Ueda, H.; Creighton, C.J.; Kato, M.; Tsuji, S.; Donehower, L.A.; Slagle, B.L.; Nakamura, H.; et al. Trans-ancestry mutational landscape of hepatocellular carcinoma genomes. Nat. Genet. 2014, 46, 1267-1273. [CrossRef] [PubMed]

103. Schulze, K.; Imbeaud, S.; Letouze, E.; Alexandrov, L.B.; Calderaro, J.; Rebouissou, S.; Couchy, G.; Meiller, C.; Shinde, J.; Soysouvanh, F.; et al. Exome sequencing of hepatocellular carcinomas identifies new mutational signatures and potential therapeutic targets. Nat. Genet. 2015, 47, 505-511. [CrossRef]

104. Cancer Genome Atlas Research Network. Comprehensive and Integrative Genomic Characterization of Hepatocellular Carcinoma. Cell 2017, 169, 1327-1341.e1323. [CrossRef] [PubMed]

105. Oda, T.; Tsuda, H.; Scarpa, A.; Sakamoto, M.; Hirohashi, S. p53 gene mutation spectrum in hepatocellular carcinoma. Cancer Res. 1992, 52, 6358-6364. [PubMed]

106. Jang, J.W.; Kim, J.S.; Kim, H.S.; Tak, K.Y.; Lee, S.K.; Nam, H.C.; Sung, P.S.; Kim, C.M.; Park, J.Y.; Bae, S.H.; et al. Significance of TERT Genetic Alterations and Telomere Length in Hepatocellular Carcinoma. Cancers 2021, 13, 2160. [CrossRef] [PubMed]

107. Legoix, P.; Bluteau, O.; Bayer, J.; Perret, C.; Balabaud, C.; Belghiti, J.; Franco, D.; Thomas, G.; Laurent-Puig, P.; Zucman-Rossi, J. Beta-catenin mutations in hepatocellular carcinoma correlate with a low rate of loss of heterozygosity. Oncogene 1999, 18, 4044-4046. [CrossRef] [PubMed]

108. Li, X.; Zhang, J.; Yang, Z.; Kang, J.; Jiang, S.; Zhang, T.; Chen, T.; Li, M.; Lv, Q.; Chen, X.; et al. The function of targeted host genes determines the oncogenicity of HBV integration in hepatocellular carcinoma. J. Hepatol. 2014, 60, 975-984. [CrossRef]

109. Zhao, L.H.; Liu, X.; Yan, H.X.; Li, W.Y.; Zeng, X.; Yang, Y.; Zhao, J.; Liu, S.P.; Zhuang, X.H.; Lin, C.; et al. Genomic and oncogenic preference of HBV integration in hepatocellular carcinoma. Nat. Commun. 2016, 7, 12992. [CrossRef]

110. Aishima, S.; Oda, Y. Pathogenesis and classification of intrahepatic cholangiocarcinoma: Different characters of perihilar large duct type versus peripheral small duct type. J. Hepatobiliary Pancreat. Sci. 2015, 22, 94-100. [CrossRef]

111. Akita, M.; Fujikura, K.; Ajiki, T.; Fukumoto, T.; Otani, K.; Azuma, T.; Itoh, T.; Ku, Y.; Zen, Y. Dichotomy in intrahepatic cholangiocarcinomas based on histologic similarities to hilar cholangiocarcinomas. Mod. Pathol. 2017, 30, 986-997. [CrossRef]

112. Komuta, M.; Spee, B.; Vander Borght, S.; De Vos, R.; Verslype, C.; Aerts, R.; Yano, H.; Suzuki, T.; Matsuda, M.; Fujii, H.; et al. Clinicopathological study on cholangiolocellular carcinoma suggesting hepatic progenitor cell origin. Hepatology 2008, 47, 1544-1556. [CrossRef]

113. Sia, D.; Villanueva, A.; Friedman, S.L.; Llovet, J.M. Liver Cancer Cell of Origin, Molecular Class, and Effects on Patient Prognosis. Gastroenterology 2017, 152, 745-761. [CrossRef]

114. Saha, S.K.; Parachoniak, C.A.; Ghanta, K.S.; Fitamant, J.; Ross, K.N.; Najem, M.S.; Gurumurthy, S.; Akbay, E.A.; Sia, D.; Cornella, H.; et al. Mutant IDH inhibits HNF-4alpha to block hepatocyte differentiation and promote biliary cancer. Nature 2014, 513, 110-114. [CrossRef]

115. Zhou, H.; Wang, H.; Zhou, D.; Wang, H.; Wang, Q.; Zou, S.; Tu, Q.; Wu, M.; Hu, H. Hepatitis B virus-associated intrahepatic cholangiocarcinoma and hepatocellular carcinoma may hold common disease process for carcinogenesis. Eur. J. Cancer 2010, 46, 1056-1061. [CrossRef] [PubMed]

116. Choo, Q.L.; Kuo, G.; Weiner, A.J.; Overby, L.R.; Bradley, D.W.; Houghton, M. Isolation of a cDNA clone derived from a blood-borne non-A, non-B viral hepatitis genome. Science 1989, 244, 359-362. [CrossRef] [PubMed]

117. Alter, H.J.; Purcell, R.H.; Shih, J.W.; Melpolder, J.C.; Houghton, M.; Choo, Q.L.; Kuo, G. Detection of antibody to hepatitis C virus in prospectively followed transfusion recipients with acute and chronic non-A, non-B hepatitis. N. Engl. J. Med. 1989, 321, 1494-1500. [CrossRef] [PubMed]

118. Tanaka, T.; Kato, N.; Cho, M.J.; Sugiyama, K.; Shimotohno, K. Structure of the 3' terminus of the hepatitis C virus genome. J. Virol. 1996, 70, 3307-3312. [CrossRef] [PubMed]

119. Kolykhalov, A.A.; Feinstone, S.M.; Rice, C.M. Identification of a highly conserved sequence element at the $3^{\prime}$ terminus of hepatitis C virus genome RNA. J. Virol. 1996, 70, 3363-3371. [CrossRef]

120. Kolykhalov, A.A.; Agapov, E.V.; Blight, K.J.; Mihalik, K.; Feinstone, S.M.; Rice, C.M. Transmission of hepatitis C by intrahepatic inoculation with transcribed RNA. Science 1997, 277, 570-574. [CrossRef]

121. Lohmann, V.; Korner, F.; Koch, J.; Herian, U.; Theilmann, L.; Bartenschlager, R. Replication of subgenomic hepatitis C virus RNAs in a hepatoma cell line. Science 1999, 285, 110-113. [CrossRef]

122. Wakita, T.; Pietschmann, T.; Kato, T.; Date, T.; Miyamoto, M.; Zhao, Z.; Murthy, K.; Habermann, A.; Krausslich, H.G.; Mizokami, M.; et al. Production of infectious hepatitis C virus in tissue culture from a cloned viral genome. Nat. Med. 2005, 11, 791-796. [CrossRef] [PubMed]

123. Pawlotsky, J.M. Interferon-Free Hepatitis C Virus Therapy. Cold Spring Harb. Perspect. Med. 2020, 10. [CrossRef] 
124. Okuda, M.; Li, K.; Beard, M.R.; Showalter, L.A.; Scholle, F.; Lemon, S.M.; Weinman, S.A. Mitochondrial injury, oxidative stress, and antioxidant gene expression are induced by hepatitis C virus core protein. Gastroenterology 2002, 122, 366-375. [CrossRef]

125. Bartsch, H.; Nair, J. Oxidative stress and lipid peroxidation-derived DNA-lesions in inflammation driven carcinogenesis. Cancer Detect. Prev. 2004, 28, 385-391. [CrossRef] [PubMed]

126. Lan, K.H.; Sheu, M.L.; Hwang, S.J.; Yen, S.H.; Chen, S.Y.; Wu, J.C.; Wang, Y.J.; Kato, N.; Omata, M.; Chang, F.Y.; et al. HCV NS5A interacts with p53 and inhibits p53-mediated apoptosis. Oncogene 2002, 21, 4801-4811. [CrossRef] [PubMed]

127. Dubourdeau, M.; Miyamura, T.; Matsuura, Y.; Alric, L.; Pipy, B.; Rousseau, D. Infection of HepG2 cells with recombinant adenovirus encoding the HCV core protein induces p21(WAF1) down-regulation-Effect of transforming growth factor beta. J. Hepatol. 2002, 37, 486-492. [CrossRef]

128. Lemon, S.M.; McGivern, D.R. Is hepatitis C virus carcinogenic? Gastroenterology 2012, 142, 1274-1278. [CrossRef]

129. Bruno, S.; Stroffolini, T.; Colombo, M.; Bollani, S.; Benvegnu, L.; Mazzella, G.; Ascione, A.; Santantonio, T.; Piccinino, F.; Andreone, P.; et al. Sustained virological response to interferon-alpha is associated with improved outcome in HCV-related cirrhosis: A retrospective study. Hepatology 2007, 45, 579-587. [CrossRef]

130. Singal, A.K.; Singh, A.; Jaganmohan, S.; Guturu, P.; Mummadi, R.; Kuo, Y.F.; Sood, G.K. Antiviral therapy reduces risk of hepatocellular carcinoma in patients with hepatitis C virus-related cirrhosis. Clin. Gastroenterol. Hepatol. 2010, 8, 192-199. [CrossRef]

131. Gupta, A.; Dixon, E. Epidemiology and risk factors: Intrahepatic cholangiocarcinoma. Hepatobiliary Surg. Nutr. 2017, 6, 101-104. [CrossRef] [PubMed]

132. Datta, S.; Chatterjee, S.; Policegoudra, R.S.; Gogoi, H.K.; Singh, L. Hepatitis viruses and non-Hodgkin's lymphoma: A review. World J. Virol. 2012, 1, 162-173. [CrossRef]

133. Hermine, O.; Lefrere, F.; Bronowicki, J.P.; Mariette, X.; Jondeau, K.; Eclache-Saudreau, V.; Delmas, B.; Valensi, F.; Cacoub, P.; Brechot, C.; et al. Regression of splenic lymphoma with villous lymphocytes after treatment of hepatitis $\mathrm{C}$ virus infection. N. Engl. J. Med. 2002, 347, 89-94. [CrossRef]

134. Arcaini, L.; Bruno, R. Hepatitis C virus infection and antiviral treatment in marginal zone lymphomas. Curr. Clin. Pharmacol. 2010, 5, 74-81. [CrossRef]

135. Epstein, M.A.; Achong, B.G.; Barr, Y.M. Virus Particles in Cultured Lymphoblasts from Burkitt's Lymphoma. Lancet 1964, 1, 702-703. [CrossRef]

136. Hutt-Fletcher, L.M. Epstein-Barr virus entry. J. Virol. 2007, 81, 7825-7832. [CrossRef] [PubMed]

137. Rowe, M.; Lear, A.L.; Croom-Carter, D.; Davies, A.H.; Rickinson, A.B. Three pathways of Epstein-Barr virus gene activation from EBNA1-positive latency in B lymphocytes. J. Virol. 1992, 66, 122-131. [CrossRef] [PubMed]

138. Mosialos, G.; Birkenbach, M.; Yalamanchili, R.; VanArsdale, T.; Ware, C.; Kieff, E. The Epstein-Barr virus transforming protein LMP1 engages signaling proteins for the tumor necrosis factor receptor family. Cell 1995, 80, 389-399. [CrossRef]

139. Cohen, J.I.; Wang, F.; Mannick, J.; Kieff, E. Epstein-Barr virus nuclear protein 2 is a key determinant of lymphocyte transformation. Proc. Natl. Acad. Sci. USA 1989, 86, 9558-9562. [CrossRef] [PubMed]

140. Grossman, S.R.; Johannsen, E.; Tong, X.; Yalamanchili, R.; Kieff, E. The Epstein-Barr virus nuclear antigen 2 transactivator is directed to response elements by the J kappa recombination signal binding protein. Proc. Natl. Acad. Sci. USA 1994, 91, 7568-7572. [CrossRef]

141. Lerner, M.R.; Andrews, N.C.; Miller, G.; Steitz, J.A. Two small RNAs encoded by Epstein-Barr virus and complexed with protein are precipitated by antibodies from patients with systemic lupus erythematosus. Proc. Natl. Acad. Sci. USA 1981, 78, 805-809. [CrossRef] [PubMed]

142. Arrand, J.R.; Rymo, L. Characterization of the major Epstein-Barr virus-specific RNA in Burkitt lymphoma-derived cells. J. Virol. 1982, 41, 376-389. [CrossRef]

143. Howe, J.G.; Shu, M.D. Epstein-Barr virus small RNA (EBER) genes: Unique transcription units that combine RNA polymerase II and III promoter elements. Cell 1989, 57, 825-834. [CrossRef]

144. Khan, G.; Coates, P.J.; Kangro, H.O.; Slavin, G. Epstein Barr virus (EBV) encoded small RNAs: Targets for detection by in situ hybridisation with oligonucleotide probes. J. Clin. Pathol. 1992, 45, 616-620. [CrossRef] [PubMed]

145. Randhawa, P.S.; Jaffe, R.; Demetris, A.J.; Nalesnik, M.; Starzl, T.E.; Chen, Y.Y.; Weiss, L.M. Expression of Epstein-Barr virus-encoded small RNA (by the EBER-1 gene) in liver specimens from transplant recipients with post-transplantation lymphoproliferative disease. N. Engl. J. Med. 1992, 327, 1710-1714. [CrossRef] [PubMed]

146. Sato, Y.; Watanabe, T.; Suzuki, C.; Abe, Y.; Masud, H.; Inagaki, T.; Yoshida, M.; Suzuki, T.; Goshima, F.; Adachi, J.; et al. S-LikePhase Cyclin-Dependent Kinases Stabilize the Epstein-Barr Virus BDLF4 Protein To Temporally Control Late Gene Transcription. J. Virol. 2019, 93. [CrossRef] [PubMed]

147. Burkitt, D. A sarcoma involving the jaws in African children. Br. J. Surg. 1958, 46, 218-223. [CrossRef] [PubMed]

148. Kitagawa, N.; Goto, M.; Kurozumi, K.; Maruo, S.; Fukayama, M.; Naoe, T.; Yasukawa, M.; Hino, K.; Suzuki, T.; Todo, S.; et al. Epstein-Barr virus-encoded poly(A)(-) RNA supports Burkitt's lymphoma growth through interleukin-10 induction. EMBO J. 2000, 19, 6742-6750. [CrossRef]

149. Yajima, M.; Kanda, T.; Takada, K. Critical role of Epstein-Barr Virus (EBV)-encoded RNA in efficient EBV-induced B-lymphocyte growth transformation. J. Virol. 2005, 79, 4298-4307. [CrossRef] [PubMed] 
150. Rawlins, D.R.; Milman, G.; Hayward, S.D.; Hayward, G.S. Sequence-specific DNA binding of the Epstein-Barr virus nuclear antigen (EBNA-1) to clustered sites in the plasmid maintenance region. Cell 1985, 42, 859-868. [CrossRef]

151. Kennedy, G.; Komano, J.; Sugden, B. Epstein-Barr virus provides a survival factor to Burkitt's lymphomas. Proc. Natl. Acad. Sci. USA 2003, 100, 14269-14274. [CrossRef]

152. Swerdlow, S.; Campo, E.; Harris, N.; Jaffe, E.; Pileri, S.; Stein, H.; Thiele, J. WHO Classification of Tumours of the Hematopoietic and Lymphoid Tissue, 4th ed.; WHO Press: Lyon, France, 2017.

153. Schmitz, R.; Young, R.M.; Ceribelli, M.; Jhavar, S.; Xiao, W.; Zhang, M.; Wright, G.; Shaffer, A.L.; Hodson, D.J.; Buras, E.; et al. Burkitt lymphoma pathogenesis and therapeutic targets from structural and functional genomics. Nature 2012, 490, 116-120. [CrossRef] [PubMed]

154. Love, C.; Sun, Z.; Jima, D.; Li, G.; Zhang, J.; Miles, R.; Richards, K.L.; Dunphy, C.H.; Choi, W.W.; Srivastava, G.; et al. The genetic landscape of mutations in Burkitt lymphoma. Nat. Genet. 2012, 44, 1321-1325. [CrossRef]

155. Richter, J.; Schlesner, M.; Hoffmann, S.; Kreuz, M.; Leich, E.; Burkhardt, B.; Rosolowski, M.; Ammerpohl, O.; Wagener, R.; Bernhart, S.H.; et al. Recurrent mutation of the ID3 gene in Burkitt lymphoma identified by integrated genome, exome and transcriptome sequencing. Nat. Genet. 2012, 44, 1316-1320. [CrossRef]

156. Momose, S.; Weissbach, S.; Pischimarov, J.; Nedeva, T.; Bach, E.; Rudelius, M.; Geissinger, E.; Staiger, A.M.; Ott, G.; Rosenwald, A. The diagnostic gray zone between Burkitt lymphoma and diffuse large B-cell lymphoma is also a gray zone of the mutational spectrum. Leukemia 2015, 29, 1789-1791. [CrossRef] [PubMed]

157. Raab-Traub, N.; Flynn, K. The structure of the termini of the Epstein-Barr virus as a marker of clonal cellular proliferation. Cell 1986, 47, 883-889. [CrossRef]

158. Pienkowska-Grela, B.; Rymkiewicz, G.; Grygalewicz, B.; Woroniecka, R.; Krawczyk, P.; Czyz-Domanska, K.; Walewski, J. Partial trisomy 11, dup(11)(q23q13), as a defect characterizing lymphomas with Burkitt pathomorphology without MYC gene rearrangement. Med. Oncol. 2011, 28, 1589-1595. [CrossRef] [PubMed]

159. Gonzalez-Farre, B.; Ramis-Zaldivar, J.E.; Salmeron-Villalobos, J.; Balague, O.; Celis, V.; Verdu-Amoros, J.; Nadeu, F.; Sabado, C.; Ferrandez, A.; Garrido, M.; et al. Burkitt-like lymphoma with 11q aberration: A germinal center-derived lymphoma genetically unrelated to Burkitt lymphoma. Haematologica 2019, 104, 1822-1829. [CrossRef]

160. Iwakiri, D.; Zhou, L.; Samanta, M.; Matsumoto, M.; Ebihara, T.; Seya, T.; Imai, S.; Fujieda, M.; Kawa, K.; Takada, K. Epstein-Barr virus (EBV)-encoded small RNA is released from EBV-infected cells and activates signaling from Toll-like receptor 3. J. Exp. Med. 2009, 206, 2091-2099. [CrossRef]

161. Oyama, T.; Ichimura, K.; Suzuki, R.; Suzumiya, J.; Ohshima, K.; Yatabe, Y.; Yokoi, T.; Kojima, M.; Kamiya, Y.; Taji, H.; et al. Senile EBV+ B-cell lymphoproliferative disorders: A clinicopathologic study of 22 patients. Am. J. Surg. Pathol. 2003, 27, 16-26. [CrossRef]

162. Oyama, T.; Yamamoto, K.; Asano, N.; Oshiro, A.; Suzuki, R.; Kagami, Y.; Morishima, Y.; Takeuchi, K.; Izumo, T.; Mori, S.; et al. Age-related EBV-associated B-cell lymphoproliferative disorders constitute a distinct clinicopathologic group: A study of 96 patients. Clin. Cancer Res. 2007, 13, 5124-5132. [CrossRef]

163. Nicolae, A.; Pittaluga, S.; Abdullah, S.; Steinberg, S.M.; Pham, T.A.; Davies-Hill, T.; Xi, L.; Raffeld, M.; Jaffe, E.S. EBV-positive large B-cell lymphomas in young patients: A nodal lymphoma with evidence for a tolerogenic immune environment. Blood 2015, 126, 863-872. [CrossRef]

164. Hans, C.P.; Weisenburger, D.D.; Greiner, T.C.; Gascoyne, R.D.; Delabie, J.; Ott, G.; Muller-Hermelink, H.K.; Campo, E.; Braziel, R.M.; Jaffe, E.S.; et al. Confirmation of the molecular classification of diffuse large B-cell lymphoma by immunohistochemistry using a tissue microarray. Blood 2004, 103, 275-282. [CrossRef] [PubMed]

165. Ikeda, T.; Gion, Y.; Sakamoto, M.; Tachibana, T.; Nishikori, A.; Nishimura, M.F.; Yoshino, T.; Sato, Y. Clinicopathological analysis of 34 Japanese patients with EBV-positive mucocutaneous ulcer. Mod. Pathol. 2020, 33, 2437-2448. [CrossRef]

166. Iuchi, K.; Ichimiya, A.; Akashi, A.; Mizuta, T.; Lee, Y.E.; Tada, H.; Mori, T.; Sawamura, K.; Lee, Y.S.; Furuse, K.; et al. NonHodgkin's lymphoma of the pleural cavity developing from long-standing pyothorax. Cancer 1987, 60, 1771-1775. [CrossRef]

167. Hongyo, T.; Kurooka, M.; Taniguchi, E.; Iuchi, K.; Nakajima, Y.; Aozasa, K.; Nomura, T. Frequent p53 mutations at dipyrimidine sites in patients with pyothorax-associated lymphoma. Cancer Res. 1998, 58, 1105-1107.

168. Yamato, H.; Ohshima, K.; Suzumiya, J.; Kikuchi, M. Evidence for local immunosuppression and demonstration of c-myc amplification in pyothorax-associated lymphoma. Histopathology 2001, 39, 163-171. [CrossRef] [PubMed]

169. Petitjean, B.; Jardin, F.; Joly, B.; Martin-Garcia, N.; Tilly, H.; Picquenot, J.M.; Briere, J.; Danel, C.; Mehaut, S.; Abd-Al-Samad, I.; et al. Pyothorax-associated lymphoma: A peculiar clinicopathologic entity derived from B cells at late stage of differentiation and with occasional aberrant dual B- and T-cell phenotype. Am. J. Surg. Pathol. 2002, 26, 724-732. [CrossRef] [PubMed]

170. Cesarman, E.; Chang, Y.; Moore, P.S.; Said, J.W.; Knowles, D.M. Kaposi's sarcoma-associated herpesvirus-like DNA sequences in AIDS-related body-cavity-based lymphomas. N. Engl. J. Med. 1995, 332, 1186-1191. [CrossRef]

171. Nador, R.G.; Cesarman, E.; Chadburn, A.; Dawson, D.B.; Ansari, M.Q.; Sald, J.; Knowles, D.M. Primary effusion lymphoma: A distinct clinicopathologic entity associated with the Kaposi's sarcoma-associated herpes virus. Blood 1996, 88, 645-656. [CrossRef]

172. Boyer, D.F.; McKelvie, P.A.; de Leval, L.; Edlefsen, K.L.; Ko, Y.H.; Aberman, Z.A.; Kovach, A.E.; Masih, A.; Nishino, H.T.; Weiss, L.M.; et al. Fibrin-associated EBV-positive Large B-Cell Lymphoma: An Indolent Neoplasm With Features Distinct From Diffuse Large B-Cell Lymphoma Associated With Chronic Inflammation. Am. J. Surg. Pathol. 2017, 41, 299-312. [CrossRef] 
173. Moreno, E.M.; Ferrer-Gomez, A.; Arias, H.P.; Garcia, I.G.; Garcia-Cosio, M. Fibrin-associated diffuse large B-cell lymphoma with plasmacytic differentiation: Case report and literature review. Diagn. Pathol. 2020, 15, 117. [CrossRef] [PubMed]

174. Liebow, A.A.; Carrington, C.R.; Friedman, P.J. Lymphomatoid granulomatosis. Hum. Pathol. 1972, 3, 457-558. [CrossRef]

175. Colby, T.V. Current histological diagnosis of lymphomatoid granulomatosis. Mod. Pathol. 2012, 25 (Suppl. S1), S39-S42. [CrossRef]

176. Puechal, X. Granulomatosis with polyangiitis (Wegener's). Jt. Bone Spine 2020, 87, 572-578. [CrossRef] [PubMed]

177. Delecluse, H.J.; Anagnostopoulos, I.; Dallenbach, F.; Hummel, M.; Marafioti, T.; Schneider, U.; Huhn, D.; Schmidt-Westhausen, A.; Reichart, P.A.; Gross, U.; et al. Plasmablastic Lymphomas of the Oral Cavity: A New Entity Associated With the Human Immunodeficiency Virus Infection. Blood 1997, 89, 1413-1420. [CrossRef] [PubMed]

178. Taddesse-Heath, L.; Meloni-Ehrig, A.; Scheerle, J.; Kelly, J.C.; Jaffe, E.S. Plasmablastic lymphoma with MYC translocation: Evidence for a common pathway in the generation of plasmablastic features. Mod. Pathol. 2010, 23, 991-999. [CrossRef] [PubMed]

179. Vega, F.; Chang, C.C.; Medeiros, L.J.; Udden, M.M.; Cho-Vega, J.H.; Lau, C.C.; Finch, C.J.; Vilchez, R.A.; McGregor, D.; Jorgensen, J.L. Plasmablastic lymphomas and plasmablastic plasma cell myelomas have nearly identical immunophenotypic profiles. Mod. Pathol. 2005, 18, 806-815. [CrossRef] [PubMed]

180. Kawa-Ha, K.; Ishihara, S.; Ninomiya, T.; Yumura-Yagi, K.; Hara, J.; Murayama, F.; Tawa, A.; Hirai, K. CD3-negative lymphoproliferative disease of granular lymphocytes containing Epstein-Barr viral DNA. J. Clin. Investig. 1989, 84, 51-55. [CrossRef]

181. Dufva, O.; Kankainen, M.; Kelkka, T.; Sekiguchi, N.; Awad, S.A.; Eldfors, S.; Yadav, B.; Kuusanmaki, H.; Malani, D.; Andersson, E.I.; et al. Aggressive natural killer-cell leukemia mutational landscape and drug profiling highlight JAK-STAT signaling as therapeutic target. Nat. Commun. 2018, 9, 1567. [CrossRef]

182. Nicolae, A.; Ganapathi, K.A.; Pham, T.H.; Xi, L.; Torres-Cabala, C.A.; Nanaji, N.M.; Zha, H.D.; Fan, Z.; Irwin, S.; Pittaluga, S.; et al. EBV-negative Aggressive NK-cell Leukemia/Lymphoma: Clinical, Pathologic, and Genetic Features. Am. J. Surg. Pathol. 2017, 41, 67-74. [CrossRef] [PubMed]

183. Quintanilla-Martinez, L.; Kumar, S.; Fend, F.; Reyes, E.; Teruya-Feldstein, J.; Kingma, D.W.; Sorbara, L.; Raffeld, M.; Straus, S.E.; Jaffe, E.S. Fulminant EBV(+) T-cell lymphoproliferative disorder following acute/chronic EBV infection: A distinct clinicopathologic syndrome. Blood 2000, 96, 443-451. [CrossRef]

184. Swerdlow, S.H.; Campo, E.; Pileri, S.A.; Harris, N.L.; Stein, H.; Siebert, R.; Advani, R.; Ghielmini, M.; Salles, G.A.; Zelenetz, A.D.; et al. The 2016 revision of the World Health Organization classification of lymphoid neoplasms. Blood 2016, 127, 2375-2390. [CrossRef]

185. George, M.R. Hemophagocytic lymphohistiocytosis: Review of etiologies and management. J. Blood Med. 2014, 5, 69-86. [CrossRef]

186. Ohshima, K.; Suzumiya, J.; Ohga, S.; Ohgami, A.; Kikuchi, M. Integrated Epstein-Barr virus (EBV) and chromosomal abnormality in chronic active EBV infection. Int. J. Cancer 1997, 71, 943-947. [CrossRef]

187. Kimura, H.; Morishima, T.; Kanegane, H.; Ohga, S.; Hoshino, Y.; Maeda, A.; Imai, S.; Okano, M.; Morio, T.; Yokota, S.; et al. Prognostic factors for chronic active Epstein-Barr virus infection. J. Infect. Dis. 2003, 187, 527-533. [CrossRef]

188. Arai, A. Advances in the Study of Chronic Active Epstein-Barr Virus Infection: Clinical Features Under the 2016 WHO Classification and Mechanisms of Development. Front. Pediatr. 2019, 7, 14. [CrossRef]

189. Iwatsuki, K.; Satoh, M.; Yamamoto, T.; Oono, T.; Morizane, S.; Ohtsuka, M.; Xu, Z.G.; Suzuki, D.; Tsuji, K. Pathogenic link between hydroa vacciniforme and Epstein-Barr virus-associated hematologic disorders. Arch. Dermatol. 2006, 142, 587-595. [CrossRef] [PubMed]

190. Cohen, J.I.; Manoli, I.; Dowdell, K.; Krogmann, T.A.; Tamura, D.; Radecki, P.; Bu, W.; Turk, S.P.; Liepshutz, K.; Hornung, R.L.; et al. Hydroa vacciniforme-like lymphoproliferative disorder: An EBV disease with a low risk of systemic illness in whites. Blood 2019, 133, 2753-2764. [CrossRef] [PubMed]

191. Gupta, G.; Man, I.; Kemmett, D. Hydroa vacciniforme: A clinical and follow-up study of 17 cases. J. Am. Acad. Dermatol. 2000, 42, 208-213. [CrossRef]

192. Kimura, H.; Hoshino, Y.; Kanegane, H.; Tsuge, I.; Okamura, T.; Kawa, K.; Morishima, T. Clinical and virologic characteristics of chronic active Epstein-Barr virus infection. Blood 2001, 98, 280-286. [CrossRef]

193. Iwata, S.; Wada, K.; Tobita, S.; Gotoh, K.; Ito, Y.; Demachi-Okamura, A.; Shimizu, N.; Nishiyama, Y.; Kimura, H. Quantitative analysis of Epstein-Barr virus (EBV)-related gene expression in patients with chronic active EBV infection. J. Gen. Virol. 2010, 91, 42-50. [CrossRef]

194. Li, Z.; Zhang, X.; Xue, W.; Zhang, Y.; Li, C.; Song, Y.; Mei, M.; Lu, L.; Wang, Y.; Zhou, Z.; et al. Recurrent GNAQ mutation encoding T96S in natural killer/T cell lymphoma. Nat. Commun. 2019, 10, 4209. [CrossRef]

195. Peng, R.J.; Han, B.W.; Cai, Q.Q.; Zuo, X.Y.; Xia, T.; Chen, J.R.; Feng, L.N.; Lim, J.Q.; Chen, S.W.; Zeng, M.S.; et al. Genomic and transcriptomic landscapes of Epstein-Barr virus in extranodal natural killer T-cell lymphoma. Leukemia 2019, 33, $1451-1462$. [CrossRef]

196. Tse, E.; Kwong, Y.L. The diagnosis and management of NK/T-cell lymphomas. J. Hematol. Oncol. 2017, 10, 85. [CrossRef]

197. Lemonnier, F.; Couronne, L.; Parrens, M.; Jais, J.P.; Travert, M.; Lamant, L.; Tournillac, O.; Rousset, T.; Fabiani, B.; Cairns, R.A.; et al. Recurrent TET2 mutations in peripheral T-cell lymphomas correlate with TFH-like features and adverse clinical parameters. Blood 2012, 120, 1466-1469. [CrossRef]

198. Sakata-Yanagimoto, M.; Enami, T.; Yoshida, K.; Shiraishi, Y.; Ishii, R.; Miyake, Y.; Muto, H.; Tsuyama, N.; Sato-Otsubo, A.; Okuno, Y.; et al. Somatic RHOA mutation in angioimmunoblastic T cell lymphoma. Nat. Genet. 2014, 46, 171-175. [CrossRef] 
199. Chiba, S.; Sakata-Yanagimoto, M. Advances in understanding of angioimmunoblastic T-cell lymphoma. Leukemia 2020, 34, 2592-2606. [CrossRef] [PubMed]

200. Streubel, B.; Vinatzer, U.; Willheim, M.; Raderer, M.; Chott, A. Novel t(5;9)(q33;q22) fuses ITK to SYK in unspecified peripheral T-cell lymphoma. Leukemia 2006, 20, 313-318. [CrossRef]

201. Huang, Y.; Moreau, A.; Dupuis, J.; Streubel, B.; Petit, B.; Le Gouill, S.; Martin-Garcia, N.; Copie-Bergman, C.; Gaillard, F.; Qubaja, M.; et al. Peripheral T-cell lymphomas with a follicular growth pattern are derived from follicular helper T cells (TFH) and may show overlapping features with angioimmunoblastic T-cell lymphomas. Am. J. Surg. Pathol. 2009, 33, 682-690. [CrossRef] [PubMed]

202. Miyoshi, H.; Sato, K.; Niino, D.; Arakawa, F.; Kimura, Y.; Kiyasu, J.; Takeuchi, M.; Yoshida, M.; Okada, Y.; Nakamura, Y.; et al. Clinicopathologic analysis of peripheral T-cell lymphoma, follicular variant, and comparison with angioimmunoblastic T-cell lymphoma: Bcl-6 expression might affect progression between these disorders. Am. J. Clin. Pathol. 2012, 137, 879-889. [CrossRef] [PubMed]

203. Hu, S.; Young, K.H.; Konoplev, S.N.; Medeiros, L.J. Follicular T-cell lymphoma: A member of an emerging family of follicular helper T-cell derived T-cell lymphomas. Hum. Pathol. 2012, 43, 1789-1798. [CrossRef] [PubMed]

204. Attygalle, A.D.; Cabecadas, J.; Gaulard, P.; Jaffe, E.S.; de Jong, D.; Ko, Y.H.; Said, J.; Klapper, W. Peripheral T-cell and NK-cell lymphomas and their mimics; taking a step forward-report on the lymphoma workshop of the XVIth meeting of the European Association for Haematopathology and the Society for Hematopathology. Histopathology 2014, 64, 171-199. [CrossRef]

205. Agostinelli, C.; Hartmann, S.; Klapper, W.; Korkolopoulou, P.; Righi, S.; Marafioti, T.; Piccaluga, P.P.; Patsouris, E.; Hansmann, M.L.; Lennert, K.; et al. Peripheral T cell lymphomas with follicular T helper phenotype: A new basket or a distinct entity? Revising Karl Lennert's personal archive. Histopathology 2011, 59, 679-691. [CrossRef]

206. Attygalle, A.D. Nodal T-cell lymphomas with a T-follicular helper cell phenotype. Diagn. Histopathol. 2018, 24, 227-236. [CrossRef]

207. Carbone, A.; Gloghini, A.; Carlo-Stella, C. Are EBV-related and EBV-unrelated Hodgkin lymphomas different with regard to susceptibility to checkpoint blockade? Blood 2018, 132, 17-22. [CrossRef]

208. Wang, H.W.; Balakrishna, J.P.; Pittaluga, S.; Jaffe, E.S. Diagnosis of Hodgkin lymphoma in the modern era. Br. J. Haematol. 2019, 184, 45-59. [CrossRef]

209. Stein, H.; Hansmann, M.L.; Lennert, K.; Brandtzaeg, P.; Gatter, K.C.; Mason, D.Y. Reed-Sternberg and Hodgkin cells in lymphocytepredominant Hodgkin's disease of nodular subtype contain J chain. Am. J. Clin. Pathol. 1986, 86, 292-297. [CrossRef]

210. Natkunam, Y.; Gratzinger, D.; Chadburn, A.; Goodlad, J.R.; Chan, J.K.C.; Said, J.; Jaffe, E.S.; de Jong, D. Immunodeficiencyassociated lymphoproliferative disorders: Time for reappraisal? Blood 2018, 132, 1871-1878. [CrossRef] [PubMed]

211. Carbone, A.; Gloghini, A. AIDS-related lymphomas: From pathogenesis to pathology. Br. J. Haematol. 2005, 130, 662-670. [CrossRef] [PubMed]

212. Hubel, K. The Changing Landscape of Lymphoma Associated with HIV Infection. Curr. Oncol. Rep. 2020, 22, 111. [CrossRef]

213. Nelson, B.P.; Nalesnik, M.A.; Bahler, D.W.; Locker, J.; Fung, J.J.; Swerdlow, S.H. Epstein-Barr virus-negative post-transplant lymphoproliferative disorders: A distinct entity? Am. J. Surg. Pathol. 2000, 24, 375-385. [CrossRef]

214. Ghobrial, I.M.; Habermann, T.M.; Macon, W.R.; Ristow, K.M.; Larson, T.S.; Walker, R.C.; Ansell, S.M.; Gores, G.J.; Stegall, M.D.; McGregor, C.G. Differences between early and late posttransplant lymphoproliferative disorders in solid organ transplant patients: Are they two different diseases? Transplantation 2005, 79, 244-247. [CrossRef]

215. Satou, A.; Tabata, T.; Miyoshi, H.; Kohno, K.; Suzuki, Y.; Yamashita, D.; Shimada, K.; Kawasaki, T.; Sato, Y.; Yoshino, T.; et al. Methotrexate-associated lymphoproliferative disorders of T-cell phenotype: Clinicopathological analysis of 28 cases. Mod. Pathol. 2019, 32, 1135-1146. [CrossRef]

216. Pathmanathan, R.; Prasad, U.; Sadler, R.; Flynn, K.; Raab-Traub, N. Clonal proliferations of cells infected with Epstein-Barr virus in preinvasive lesions related to nasopharyngeal carcinoma. N. Engl. J. Med. 1995, 333, 693-698. [CrossRef]

217. Chang, Y.L.; Wu, C.T.; Shih, J.Y.; Lee, Y.C. New aspects in clinicopathologic and oncogene studies of 23 pulmonary lymphoepithelioma-like carcinomas. Am. J. Surg. Pathol. 2002, 26, 715-723. [CrossRef]

218. Miller, W.E.; Earp, H.S.; Raab-Traub, N. The Epstein-Barr virus latent membrane protein 1 induces expression of the epidermal growth factor receptor. J. Virol. 1995, 69, 4390-4398. [CrossRef] [PubMed]

219. Lo, A.K.; Lung, R.W.; Dawson, C.W.; Young, L.S.; Ko, C.W.; Yeung, W.W.; Kang, W.; To, K.F.; Lo, K.W. Activation of sterol regulatory element-binding protein 1 (SREBP1)-mediated lipogenesis by the Epstein-Barr virus-encoded latent membrane protein 1 (LMP1) promotes cell proliferation and progression of nasopharyngeal carcinoma. J. Pathol. 2018, 246, 180-190. [CrossRef] [PubMed]

220. Chung, G.T.; Lou, W.P.; Chow, C.; To, K.F.; Choy, K.W.; Leung, A.W.; Tong, C.Y.; Yuen, J.W.; Ko, C.W.; Yip, T.T.; et al. Constitutive activation of distinct NF-kappaB signals in EBV-associated nasopharyngeal carcinoma. J. Pathol. 2013, 231, 311-322. [CrossRef] [PubMed]

221. Kwong, J.; Lo, K.W.; To, K.F.; Teo, P.M.; Johnson, P.J.; Huang, D.P. Promoter hypermethylation of multiple genes in nasopharyngeal carcinoma. Clin. Cancer Res. 2002, 8, 131-137. [PubMed]

222. Garcia, M.J.; Martinez-Delgado, B.; Cebrian, A.; Martinez, A.; Benitez, J.; Rivas, C. Different incidence and pattern of p15INK4b and p16INK4a promoter region hypermethylation in Hodgkin's and CD30-Positive non-Hodgkin's lymphomas. Am. J. Pathol. 2002, 161, 1007-1013. [CrossRef] 
223. Chong, J.M.; Sakuma, K.; Sudo, M.; Ushiku, T.; Uozaki, H.; Shibahara, J.; Nagai, H.; Funata, N.; Taniguchi, H.; Aburatani, H.; et al. Global and non-random CpG-island methylation in gastric carcinoma associated with Epstein-Barr virus. Cancer Sci. 2003, 94, 76-80. [CrossRef] [PubMed]

224. Chang, M.S.; Uozaki, H.; Chong, J.M.; Ushiku, T.; Sakuma, K.; Ishikawa, S.; Hino, R.; Barua, R.R.; Iwasaki, Y.; Arai, K.; et al. CpG island methylation status in gastric carcinoma with and without infection of Epstein-Barr virus. Clin. Cancer Res. 2006, 12, 2995-3002. [CrossRef] [PubMed]

225. Toyota, M.; Ahuja, N.; Ohe-Toyota, M.; Herman, J.G.; Baylin, S.B.; Issa, J.P. CpG island methylator phenotype in colorectal cancer. Proc. Natl. Acad. Sci. USA 1999, 96, 8681-8686. [CrossRef]

226. Tsai, C.L.; Li, H.P.; Lu, Y.J.; Hsueh, C.; Liang, Y.; Chen, C.L.; Tsao, S.W.; Tse, K.P.; Yu, J.S.; Chang, Y.S. Activation of DNA methyltransferase 1 by EBV LMP1 Involves c-Jun NH(2)-terminal kinase signaling. Cancer Res. 2006, 66, 11668-11676. [CrossRef]

227. Hino, R.; Uozaki, H.; Murakami, N.; Ushiku, T.; Shinozaki, A.; Ishikawa, S.; Morikawa, T.; Nakaya, T.; Sakatani, T.; Takada, K.; et al. Activation of DNA methyltransferase 1 by EBV latent membrane protein 2A leads to promoter hypermethylation of PTEN gene in gastric carcinoma. Cancer Res. 2009, 69, 2766-2774. [CrossRef]

228. Watanabe, H.; Enjoji, M.; Imai, T. Gastric carcinoma with lymphoid stroma. Its morphologic characteristics and prognostic correlations. Cancer 1976, 38, 232-243. [CrossRef]

229. Gullo, I.; Oliveira, P.; Athelogou, M.; Goncalves, G.; Pinto, M.L.; Carvalho, J.; Valente, A.; Pinheiro, H.; Andrade, S.; Almeida, G.M.; et al. New insights into the inflamed tumor immune microenvironment of gastric cancer with lymphoid stroma: From morphology and digital analysis to gene expression. Gastric Cancer 2019, 22, 77-90. [CrossRef]

230. Murphy, G.; Pfeiffer, R.; Camargo, M.C.; Rabkin, C.S. Meta-analysis shows that prevalence of Epstein-Barr virus-positive gastric cancer differs based on sex and anatomic location. Gastroenterology 2009, 137, 824-833. [CrossRef] [PubMed]

231. Cancer Genome Atlas Research Network. Comprehensive molecular characterization of gastric adenocarcinoma. Nature 2014, 513, 202-209. [CrossRef]

232. Cancer Genome Atlas Research Network. Comprehensive and Integrated Genomic Characterization of Adult Soft Tissue Sarcomas. Cell 2017, 171, 950-965.e28. [CrossRef] [PubMed]

233. Chadwick, E.G.; Connor, E.J.; Hanson, I.C.; Joshi, V.V.; Abu-Farsakh, H.; Yogev, R.; McSherry, G.; McClain, K.; Murphy, S.B. Tumors of smooth-muscle origin in HIV-infected children. JAMA 1990, 263, 3182-3184. [CrossRef] [PubMed]

234. Prevot, S.; Neris, J.; de Saint Maur, P.P. Detection of Epstein Barr virus in an hepatic leiomyomatous neoplasm in an adult human immunodeficiency virus 1-infected patient. Virchows Arch. 1994, 425, 321-325. [CrossRef]

235. Hussein, K.; Rath, B.; Ludewig, B.; Kreipe, H.; Jonigk, D. Clinico-pathological characteristics of different types of immunodeficiency-associated smooth muscle tumours. Eur. J. Cancer 2014, 50, 2417-2424. [CrossRef] [PubMed]

236. Moore Dalal, K.; Antonescu, C.R.; Dematteo, R.P.; Maki, R.G. EBV-Associated Smooth Muscle Neoplasms: Solid Tumors Arising in the Presence of Immunosuppression and Autoimmune Diseases. Sarcoma 2008, 2008, 859407. [CrossRef]

237. Ong, K.W.; Teo, M.; Lee, V.; Ong, D.; Lee, A.; Tan, C.S.; Vathsala, A.; Toh, H.C. Expression of EBV latent antigens, mammalian target of rapamycin, and tumor suppression genes in EBV-positive smooth muscle tumors: Clinical and therapeutic implications. Clin. Cancer Res. 2009, 15, 5350-5358. [CrossRef]

238. Tan, C.S.; Loh, H.L.; Foo, M.W.; Choong, L.H.; Wong, K.S.; Kee, T.Y. Epstein-Barr virus-associated smooth muscle tumors after kidney transplantation: Treatment and outcomes in a single center. Clin. Transplant. 2013, 27, E462-E468. [CrossRef] [PubMed]

239. Chang, Y.; Cesarman, E.; Pessin, M.S.; Lee, F.; Culpepper, J.; Knowles, D.M.; Moore, P.S. Identification of herpesvirus-like DNA sequences in AIDS-associated Kaposi's sarcoma. Science 1994, 266, 1865-1869. [CrossRef]

240. Akula, S.M.; Pramod, N.P.; Wang, F.Z.; Chandran, B. Integrin alpha3beta1 (CD 49c/29) is a cellular receptor for Kaposi's sarcoma-associated herpesvirus (KSHV/HHV-8) entry into the target cells. Cell 2002, 108, 407-419. [CrossRef]

241. Hahn, A.S.; Kaufmann, J.K.; Wies, E.; Naschberger, E.; Panteleev-Ivlev, J.; Schmidt, K.; Holzer, A.; Schmidt, M.; Chen, J.; Konig, S.; et al. The ephrin receptor tyrosine kinase A2 is a cellular receptor for Kaposi's sarcoma-associated herpesvirus. Nat. Med. 2012, 18, 961-966. [CrossRef] [PubMed]

242. Sakurada, S.; Katano, H.; Sata, T.; Ohkuni, H.; Watanabe, T.; Mori, S. Effective human herpesvirus 8 infection of human umbilical vein endothelial cells by cell-mediated transmission. J. Virol. 2001, 75, 7717-7722. [CrossRef]

243. Aoki, Y.; Jaffe, E.S.; Chang, Y.; Jones, K.; Teruya-Feldstein, J.; Moore, P.S.; Tosato, G. Angiogenesis and hematopoiesis induced by Kaposi's sarcoma-associated herpesvirus-encoded interleukin-6. Blood 1999, 93, 4034-4043. [CrossRef]

244. Ballestas, M.E.; Chatis, P.A.; Kaye, K.M. Efficient persistence of extrachromosomal KSHV DNA mediated by latency-associated nuclear antigen. Science 1999, 284, 641-644. [CrossRef] [PubMed]

245. Friborg, J., Jr.; Kong, W.; Hottiger, M.O.; Nabel, G.J. p53 inhibition by the LANA protein of KSHV protects against cell death. Nature 1999, 402, 889-894. [CrossRef] [PubMed]

246. Fujimuro, M.; Wu, F.Y.; ApRhys, C.; Kajumbula, H.; Young, D.B.; Hayward, G.S.; Hayward, S.D. A novel viral mechanism for dysregulation of beta-catenin in Kaposi's sarcoma-associated herpesvirus latency. Nat. Med. 2003, 9, 300-306. [CrossRef]

247. Kamiyango, W.; Villiera, J.; Silverstein, A.; Peckham-Gregory, E.; Campbell, L.R.; El-Mallawany, N.K. Navigating the heterogeneous landscape of pediatric Kaposi sarcoma. Cancer Metastasis Rev. 2019, 38, 749-758. [CrossRef]

248. Chabay, P.; Lens, D.; Hassan, R.; Rodriguez Pinilla, S.M.; Valvert Gamboa, F.; Rivera, I.; Huaman Garaicoa, F.; Ranuncolo, S.M.; Barrionuevo, C.; Morales Sanchez, A.; et al. Lymphotropic Viruses EBV, KSHV and HTLV in Latin America: Epidemiology and Associated Malignancies. A Literature-Based Study by the RIAL-CYTED. Cancers 2020, 12, 2166. [CrossRef] 
249. Pantanowitz, L.; Dezube, B.J.; Pinkus, G.S.; Tahan, S.R. Histological characterization of regression in acquired immunodeficiency syndrome-related Kaposi's sarcoma. J. Cutan. Pathol. 2004, 31, 26-34. [CrossRef] [PubMed]

250. Katano, H.; Sato, Y.; Kurata, T.; Mori, S.; Sata, T. High expression of HHV-8-encoded ORF73 protein in spindle-shaped cells of Kaposi's sarcoma. Am. J. Pathol. 1999, 155, 47-52. [CrossRef]

251. Bower, M.; Dalla Pria, A.; Coyle, C.; Andrews, E.; Tittle, V.; Dhoot, S.; Nelson, M. Prospective stage-stratified approach to AIDS-related Kaposi's sarcoma. J. Clin. Oncol. 2014, 32, 409-414. [CrossRef]

252. Suda, T.; Katano, H.; Delsol, G.; Kakiuchi, C.; Nakamura, T.; Shiota, M.; Sata, T.; Higashihara, M.; Mori, S. HHV-8 infection status of AIDS-unrelated and AIDS-associated multicentric Castleman's disease. Pathol. Int. 2001, 51, 671-679. [CrossRef] [PubMed]

253. Oksenhendler, E.; Boulanger, E.; Galicier, L.; Du, M.Q.; Dupin, N.; Diss, T.C.; Hamoudi, R.; Daniel, M.T.; Agbalika, F.; Boshoff, C.; et al. High incidence of Kaposi sarcoma-associated herpesvirus-related non-Hodgkin lymphoma in patients with HIV infection and multicentric Castleman disease. Blood 2002, 99, 2331-2336. [CrossRef]

254. Du, M.Q.; Diss, T.C.; Liu, H.; Ye, H.; Hamoudi, R.A.; Cabecadas, J.; Dong, H.Y.; Harris, N.L.; Chan, J.K.; Rees, J.W.; et al. KSHVand EBV-associated germinotropic lymphoproliferative disorder. Blood 2002, 100, 3415-3418. [CrossRef]

255. Bhavsar, T.; Lee, J.C.; Perner, Y.; Raffeld, M.; Xi, L.; Pittaluga, S.; Jaffe, E.S. KSHV-associated and EBV-associated Germinotropic Lymphoproliferative Disorder: New Findings and Review of the Literature. Am. J. Surg. Pathol. 2017, 41, 795-800. [CrossRef]

256. Gonzalez-Farre, B.; Martinez, D.; Lopez-Guerra, M.; Xipell, M.; Monclus, E.; Rovira, J.; Garcia, F.; Lopez-Guillermo, A.; Colomo, L.; Campo, E.; et al. HHV8-related lymphoid proliferations: A broad spectrum of lesions from reactive lymphoid hyperplasia to overt lymphoma. Mod. Pathol. 2017, 30, 745-760. [CrossRef]

257. Chadburn, A.; Hyjek, E.; Mathew, S.; Cesarman, E.; Said, J.; Knowles, D.M. KSHV-positive solid lymphomas represent an extra-cavitary variant of primary effusion lymphoma. Am. J. Surg. Pathol. 2004, 28, 1401-1416. [CrossRef]

258. Pan, Z.G.; Zhang, Q.Y.; Lu, Z.B.; Quinto, T.; Rozenvald, I.B.; Liu, L.T.; Wilson, D.; Reddy, V.; Huang, Q.; Wang, H.Y.; et al. Extracavitary KSHV-associated large B-Cell lymphoma: A distinct entity or a subtype of primary effusion lymphoma? Study of 9 cases and review of an additional 43 cases. Am. J. Surg. Pathol. 2012, 36, 1129-1140. [CrossRef] [PubMed]

259. Alexanian, S.; Said, J.; Lones, M.; Pullarkat, S.T. KSHV/HHV8-negative effusion-based lymphoma, a distinct entity associated with fluid overload states. Am. J. Surg. Pathol. 2013, 37, 241-249. [CrossRef] [PubMed]

260. Iwaki, N.; Fajgenbaum, D.C.; Nabel, C.S.; Gion, Y.; Kondo, E.; Kawano, M.; Masunari, T.; Yoshida, I.; Moro, H.; Nikkuni, K.; et al. Clinicopathologic analysis of TAFRO syndrome demonstrates a distinct subtype of HHV-8-negative multicentric Castleman disease. Am. J. Hematol. 2016, 91, 220-226. [CrossRef]

261. Katano, H.; Sato, Y.; Kurata, T.; Mori, S.; Sata, T. Expression and localization of human herpesvirus 8-encoded proteins in primary effusion lymphoma, Kaposi's sarcoma, and multicentric Castleman's disease. Virology 2000, 269, 335-344. [CrossRef] [PubMed]

262. Soulier, J.; Grollet, L.; Oksenhendler, E.; Cacoub, P.; Cazals-Hatem, D.; Babinet, P.; d'Agay, M.F.; Clauvel, J.P.; Raphael, M.; Degos, L.; et al. Kaposi's sarcoma-associated herpesvirus-like DNA sequences in multicentric Castleman's disease. Blood 1995, 86, 1276-1280. [CrossRef] [PubMed]

263. Feng, H.; Shuda, M.; Chang, Y.; Moore, P.S. Clonal integration of a polyomavirus in human Merkel cell carcinoma. Science 2008, 319, 1096-1100. [CrossRef] [PubMed]

264. Feng, H.; Taylor, J.L.; Benos, P.V.; Newton, R.; Waddell, K.; Lucas, S.B.; Chang, Y.; Moore, P.S. Human transcriptome subtraction by using short sequence tags to search for tumor viruses in conjunctival carcinoma. J. Virol. 2007, 81, 11332-11340. [CrossRef] [PubMed]

265. Pipas, J.M. Common and unique features of T antigens encoded by the polyomavirus group. J. Virol. 1992, 66, 3979-3985. [CrossRef]

266. Shuda, M.; Feng, H.; Kwun, H.J.; Rosen, S.T.; Gjoerup, O.; Moore, P.S.; Chang, Y. T antigen mutations are a human tumor-specific signature for Merkel cell polyomavirus. Proc. Natl. Acad. Sci. USA 2008, 105, 16272-16277. [CrossRef]

267. Ludlow, J.W.; Shon, J.; Pipas, J.M.; Livingston, D.M.; DeCaprio, J.A. The retinoblastoma susceptibility gene product undergoes cell cycle-dependent dephosphorylation and binding to and release from SV40 large T. Cell 1990, 60, 387-396. [CrossRef]

268. Houben, R.; Adam, C.; Baeurle, A.; Hesbacher, S.; Grimm, J.; Angermeyer, S.; Henzel, K.; Hauser, S.; Elling, R.; Brocker, E.B.; et al. An intact retinoblastoma protein-binding site in Merkel cell polyomavirus large $\mathrm{T}$ antigen is required for promoting growth of Merkel cell carcinoma cells. Int. J. Cancer 2012, 130, 847-856. [CrossRef]

269. Kwun, H.J.; Guastafierro, A.; Shuda, M.; Meinke, G.; Bohm, A.; Moore, P.S.; Chang, Y. The minimum replication origin of merkel cell polyomavirus has a unique large T-antigen loading architecture and requires small T-antigen expression for optimal replication. J. Virol. 2009, 83, 12118-12128. [CrossRef]

270. Sastre-Garau, X.; Peter, M.; Avril, M.F.; Laude, H.; Couturier, J.; Rozenberg, F.; Almeida, A.; Boitier, F.; Carlotti, A.; Couturaud, B.; et al. Merkel cell carcinoma of the skin: Pathological and molecular evidence for a causative role of MCV in oncogenesis. J. Pathol. 2009, 218, 48-56. [CrossRef]

271. Erstad, D.J.; Cusack, J.C., Jr. Mutational analysis of merkel cell carcinoma. Cancers 2014, 6, 2116-2136. [CrossRef]

272. Paulson, K.G.; Lemos, B.D.; Feng, B.; Jaimes, N.; Penas, P.F.; Bi, X.; Maher, E.; Cohen, L.; Leonard, J.H.; Granter, S.R.; et al. Array-CGH reveals recurrent genomic changes in Merkel cell carcinoma including amplification of L-Myc. J. Investig. Dermatol. 2009, 129, 1547-1555. [CrossRef]

273. Toker, C. Trabecular carcinoma of the skin. Arch. Dermatol. 1972, 105, 107-110. [CrossRef] [PubMed] 
274. Heath, M.; Jaimes, N.; Lemos, B.; Mostaghimi, A.; Wang, L.C.; Penas, P.F.; Nghiem, P. Clinical characteristics of Merkel cell carcinoma at diagnosis in 195 patients: The AEIOU features. J. Am. Acad. Dermatol. 2008, 58, 375-381. [CrossRef] [PubMed]

275. Walsh, N.M. Complete spontaneous regression of Merkel cell carcinoma (1986-2016): A 30 year perspective. J. Cutan. Pathol. 2016, 43, 1150-1154. [CrossRef] [PubMed]

276. Kelly, J.W.; Sagebiel, R.W.; Blois, M.S. Regression in malignant melanoma. A histologic feature without independent prognostic significance. Cancer 1985, 56, 2287-2291. [CrossRef]

277. Busam, K.J.; Jungbluth, A.A.; Rekthman, N.; Coit, D.; Pulitzer, M.; Bini, J.; Arora, R.; Hanson, N.C.; Tassello, J.A.; Frosina, D.; et al. Merkel cell polyomavirus expression in merkel cell carcinomas and its absence in combined tumors and pulmonary neuroendocrine carcinomas. Am. J. Surg. Pathol. 2009, 33, 1378-1385. [CrossRef] [PubMed]

278. Goh, G.; Walradt, T.; Markarov, V.; Blom, A.; Riaz, N.; Doumani, R.; Stafstrom, K.; Moshiri, A.; Yelistratova, L.; Levinsohn, J.; et al. Mutational landscape of MCPyV-positive and MCPyV-negative Merkel cell carcinomas with implications for immunotherapy. Oncotarget 2016, 7, 3403-3415. [CrossRef]

279. Pulitzer, M.P.; Brannon, A.R.; Berger, M.F.; Louis, P.; Scott, S.N.; Jungbluth, A.A.; Coit, D.G.; Brownell, I.; Busam, K.J. Cutaneous squamous and neuroendocrine carcinoma: Genetically and immunohistochemically different from Merkel cell carcinoma. Mod. Pathol. 2015, 28, 1023-1032. [CrossRef]

280. Miner, A.G.; Patel, R.M.; Wilson, D.A.; Procop, G.W.; Minca, E.C.; Fullen, D.R.; Harms, P.W.; Billings, S.D. Cytokeratin 20-negative Merkel cell carcinoma is infrequently associated with the Merkel cell polyomavirus. Mod. Pathol. 2015, 28, 498-504. [CrossRef]

281. Hendry, S.; Salgado, R.; Gevaert, T.; Russell, P.A.; John, T.; Thapa, B.; Christie, M.; van de Vijver, K.; Estrada, M.V.; GonzalezEricsson, P.I.; et al. Assessing Tumor-infiltrating Lymphocytes in Solid Tumors: A Practical Review for Pathologists and Proposal for a Standardized Method From the International Immunooncology Biomarkers Working Group: Part 1: Assessing the Host Immune Response, TILs in Invasive Breast Carcinoma and Ductal Carcinoma In Situ, Metastatic Tumor Deposits and Areas for Further Research. Adv. Anat. Pathol. 2017, 24, 235-251. [CrossRef]

282. Hendry, S.; Salgado, R.; Gevaert, T.; Russell, P.A.; John, T.; Thapa, B.; Christie, M.; van de Vijver, K.; Estrada, M.V.; GonzalezEricsson, P.I.; et al. Assessing Tumor-Infiltrating Lymphocytes in Solid Tumors: A Practical Review for Pathologists and Proposal for a Standardized Method from the International Immuno-Oncology Biomarkers Working Group: Part 2: TILs in Melanoma, Gastrointestinal Tract Carcinomas, Non-Small Cell Lung Carcinoma and Mesothelioma, Endometrial and Ovarian Carcinomas, Squamous Cell Carcinoma of the Head and Neck, Genitourinary Carcinomas, and Primary Brain Tumors. Adv. Anat. Pathol. 2017, 24, 311-335. [CrossRef] [PubMed]

283. Paulson, K.G.; Iyer, J.G.; Simonson, W.T.; Blom, A.; Thibodeau, R.M.; Schmidt, M.; Pietromonaco, S.; Sokil, M.; Warton, E.M.; Asgari, M.M.; et al. CD8+ lymphocyte intratumoral infiltration as a stage-independent predictor of Merkel cell carcinoma survival: A population-based study. Am. J. Clin. Pathol. 2014, 142, 452-458. [CrossRef] [PubMed]

284. Kaufman, H.L.; Russell, J.; Hamid, O.; Bhatia, S.; Terheyden, P.; D’Angelo, S.P.; Shih, K.C.; Lebbé, C.; Linette, G.P.; Milella, M.; et al. Avelumab in patients with chemotherapy-refractory metastatic Merkel cell carcinoma: A multicentre, single-group, open-label, phase 2 trial. Lancet Oncol. 2016, 17, 1374-1385. [CrossRef]

285. Poiesz, B.J.; Ruscetti, F.W.; Gazdar, A.F.; Bunn, P.A.; Minna, J.D.; Gallo, R.C. Detection and isolation of type C retrovirus particles from fresh and cultured lymphocytes of a patient with cutaneous T-cell lymphoma. Proc. Natl. Acad. Sci. USA 1980, 77, 7415-7419. [CrossRef] [PubMed]

286. Uchiyama, T.; Yodoi, J.; Sagawa, K.; Takatsuki, K.; Uchino, H. Adult T-cell leukemia: Clinical and hematologic features of 16 cases. Blood 1977, 50, 481-492. [CrossRef] [PubMed]

287. Fan, N.; Gavalchin, J.; Paul, B.; Wells, K.H.; Lane, M.J.; Poiesz, B.J. Infection of peripheral blood mononuclear cells and cell lines by cell-free human T-cell lymphoma/leukemia virus type I. J. Clin. Microbiol. 1992, 30, 905-910. [CrossRef] [PubMed]

288. Temin, H.M.; Mizutani, S. RNA-dependent DNA polymerase in virions of Rous sarcoma virus. Nature 1970, 226, 1211-1213. [CrossRef]

289. Doi, K.; Wu, X.; Taniguchi, Y.; Yasunaga, J.; Satou, Y.; Okayama, A.; Nosaka, K.; Matsuoka, M. Preferential selection of human T-cell leukemia virus type I provirus integration sites in leukemic versus carrier states. Blood 2005, 106, 1048-1053. [CrossRef]

290. Hinuma, Y.; Nagata, K.; Hanaoka, M.; Nakai, M.; Matsumoto, T.; Kinoshita, K.I.; Shirakawa, S.; Miyoshi, I. Adult T-cell leukemia: Antigen in an ATL cell line and detection of antibodies to the antigen in human sera. Proc. Natl. Acad. Sci. USA 1981, 78, 6476-6480. [CrossRef] [PubMed]

291. Osame, M.; Usuku, K.; Izumo, S.; Ijichi, N.; Amitani, H.; Igata, A.; Matsumoto, M.; Tara, M. HTLV-I associated myelopathy, a new clinical entity. Lancet 1986, 1, 1031-1032. [CrossRef]

292. Kamoi, K.; Mochizuki, M. HTLV-1 uveitis. Front. Microbiol. 2012, 3, 270. [CrossRef] [PubMed]

293. Grassmann, R.; Dengler, C.; Muller-Fleckenstein, I.; Fleckenstein, B.; McGuire, K.; Dokhelar, M.C.; Sodroski, J.G.; Haseltine, W.A. Transformation to continuous growth of primary human T lymphocytes by human T-cell leukemia virus type I X-region genes transduced by a Herpesvirus saimiri vector. Proc. Natl. Acad. Sci. USA 1989, 86, 3351-3355. [CrossRef]

294. Kashanchi, F.; Brady, J.N. Transcriptional and post-transcriptional gene regulation of HTLV-1. Oncogene 2005, $24,5938-5951$. [CrossRef]

295. Takeda, S.; Maeda, M.; Morikawa, S.; Taniguchi, Y.; Yasunaga, J.; Nosaka, K.; Tanaka, Y.; Matsuoka, M. Genetic and epigenetic inactivation of tax gene in adult T-cell leukemia cells. Int. J. Cancer 2004, 109, 559-567. [CrossRef] [PubMed] 
296. Taniguchi, Y.; Nosaka, K.; Yasunaga, J.; Maeda, M.; Mueller, N.; Okayama, A.; Matsuoka, M. Silencing of human T-cell leukemia virus type I gene transcription by epigenetic mechanisms. Retrovirology 2005, 2, 64. [CrossRef] [PubMed]

297. Satou, Y.; Yasunaga, J.; Yoshida, M.; Matsuoka, M. HTLV-I basic leucine zipper factor gene mRNA supports proliferation of adult T cell leukemia cells. Proc. Natl. Acad. Sci. USA 2006, 103, 720-725. [CrossRef] [PubMed]

298. Fan, J.; Ma, G.; Nosaka, K.; Tanabe, J.; Satou, Y.; Koito, A.; Wain-Hobson, S.; Vartanian, J.P.; Matsuoka, M. APOBEC3G generates nonsense mutations in human T-cell leukemia virus type 1 proviral genomes in vivo. J. Virol. 2010, 84, 7278-7287. [CrossRef]

299. Satou, Y.; Yasunaga, J.; Zhao, T.; Yoshida, M.; Miyazato, P.; Takai, K.; Shimizu, K.; Ohshima, K.; Green, P.L.; Ohkura, N.; et al. HTLV-1 bZIP factor induces T-cell lymphoma and systemic inflammation in vivo. PLoS Pathog. 2011, 7, e1001274. [CrossRef] [PubMed]

300. Gaudray, G.; Gachon, F.; Basbous, J.; Biard-Piechaczyk, M.; Devaux, C.; Mesnard, J.M. The complementary strand of the human T-cell leukemia virus type 1 RNA genome encodes a bZIP transcription factor that down-regulates viral transcription. J. Virol. 2002, 76, 12813-12822. [CrossRef]

301. Zhao, T.; Yasunaga, J.; Satou, Y.; Nakao, M.; Takahashi, M.; Fujii, M.; Matsuoka, M. Human T-cell leukemia virus type 1 bZIP factor selectively suppresses the classical pathway of NF-kappaB. Blood 2009, 113, 2755-2764. [CrossRef]

302. Matsuoka, M.; Yasunaga, J. Human T-cell leukemia virus type 1: Replication, proliferation and propagation by Tax and HTLV1 bZIP factor. Curr. Opin. Virol. 2013, 3, 684-691. [CrossRef]

303. Ma, G.; Yasunaga, J.; Fan, J.; Yanagawa, S.; Matsuoka, M. HTLV-1 bZIP factor dysregulates the Wnt pathways to support proliferation and migration of adult T-cell leukemia cells. Oncogene 2013, 32, 4222-4230. [CrossRef]

304. Mehta-Shah, N.; Ratner, L.; Horwitz, S.M. Adult T-Cell Leukemia/Lymphoma. J. Oncol. Pract. 2017, 13, 487-492. [CrossRef]

305. Karube, K.; Ohshima, K.; Tsuchiya, T.; Yamaguchi, T.; Kawano, R.; Suzumiya, J.; Utsunomiya, A.; Harada, M.; Kikuchi, M. Expression of FoxP3, a key molecule in CD4CD25 regulatory T cells, in adult T-cell leukaemia/lymphoma cells. Br. J. Haematol. 2004, 126, 81-84. [CrossRef] [PubMed]

306. Shimoyama, M. Diagnostic criteria and classification of clinical subtypes of adult T-cell leukaemia-lymphoma. A report from the Lymphoma Study Group (1984-1987). Br. J. Haematol. 1991, 79, 428-437. [CrossRef] [PubMed]

307. Power, C.A.; Meyer, A.; Nemeth, K.; Bacon, K.B.; Hoogewerf, A.J.; Proudfoot, A.E.; Wells, T.N. Molecular cloning and functional expression of a novel CC chemokine receptor cDNA from a human basophilic cell line. J. Biol. Chem. 1995, 270, 19495-19500. [CrossRef] [PubMed]

308. Samson, M.; Soularue, P.; Vassart, G.; Parmentier, M. The genes encoding the human CC-chemokine receptors CC-CKR1 to CC-CKR5 (CMKBR1-CMKBR5) are clustered in the p21.3-p24 region of chromosome 3. Genomics 1996, 36, 522-526. [CrossRef]

309. Kunicki, M.A.; Amaya Hernandez, L.C.; Davis, K.L.; Bacchetta, R.; Roncarolo, M.G. Identity and Diversity of Human Peripheral Th and T Regulatory Cells Defined by Single-Cell Mass Cytometry. J. Immunol. 2018, 200, 336-346. [CrossRef]

310. Ishida, T.; Utsunomiya, A.; Jo, T.; Yamamoto, K.; Kato, K.; Yoshida, S.; Takemoto, S.; Suzushima, H.; Kobayashi, Y.; Imaizumi, Y.; et al. Mogamulizumab for relapsed adult T-cell leukemia-lymphoma: Updated follow-up analysis of phase I and II studies. Cancer Sci. 2017, 108, 2022-2029. [CrossRef] [PubMed]

311. Bonecchi, R.; Bianchi, G.; Bordignon, P.P.; D’Ambrosio, D.; Lang, R.; Borsatti, A.; Sozzani, S.; Allavena, P.; Gray, P.A.; Mantovani, A.; et al. Differential expression of chemokine receptors and chemotactic responsiveness of type $1 \mathrm{~T}$ helper cells (Th1s) and Th2s. J. Exp. Med. 1998, 187, 129-134. [CrossRef]

312. Yoshie, O.; Fujisawa, R.; Nakayama, T.; Harasawa, H.; Tago, H.; Izawa, D.; Hieshima, K.; Tatsumi, Y.; Matsushima, K.; Hasegawa, H.; et al. Frequent expression of CCR4 in adult T-cell leukemia and human T-cell leukemia virus type 1-transformed T cells. Blood 2002, 99, 1505-1511. [CrossRef]

313. Ishida, T.; Utsunomiya, A.; Iida, S.; Inagaki, H.; Takatsuka, Y.; Kusumoto, S.; Takeuchi, G.; Shimizu, S.; Ito, M.; Komatsu, H.; et al Clinical significance of CCR4 expression in adult T-cell leukemia/lymphoma: Its close association with skin involvement and unfavorable outcome. Clin. Cancer Res. 2003, 9, 3625-3634.

314. Kataoka, K.; Nagata, Y.; Kitanaka, A.; Shiraishi, Y.; Shimamura, T.; Yasunaga, J.; Totoki, Y.; Chiba, K.; Sato-Otsubo, A.; Nagae, G.; et al. Integrated molecular analysis of adult $\mathrm{T}$ cell leukemia/lymphoma. Nat. Genet. 2015, 47, 1304-1315. [CrossRef]

315. Nakagawa, M.; Schmitz, R.; Xiao, W.; Goldman, C.K.; Xu, W.; Yang, Y.; Yu, X.; Waldmann, T.A.; Staudt, L.M. Gain-of-function CCR4 mutations in adult T cell leukemia/lymphoma. J. Exp. Med. 2014, 211, 2497-2505. [CrossRef] [PubMed]

316. Yoshida, N.; Miyoshi, H.; Kato, T.; Sakata-Yanagimoto, M.; Niino, D.; Taniguchi, H.; Moriuchi, Y.; Miyahara, M.; Kurita, D.; Sasaki, Y.; et al. CCR4 frameshift mutation identifies a distinct group of adult T cell leukaemia/lymphoma with poor prognosis. J. Pathol. 2016, 238, 621-626. [CrossRef]

317. Sakamoto, Y.; Ishida, T.; Masaki, A.; Murase, T.; Yonekura, K.; Tashiro, Y.; Tokunaga, M.; Utsunomiya, A.; Ito, A.; Kusumoto, S.; et al. CCR4 mutations associated with superior outcome of adult T-cell leukemia/lymphoma under mogamulizumab treatment. Blood 2018, 132, 758-761. [CrossRef]

318. Sato, T.; Coler-Reilly, A.L.G.; Yagishita, N.; Araya, N.; Inoue, E.; Furuta, R.; Watanabe, T.; Uchimaru, K.; Matsuoka, M.; Matsumoto, N.; et al. Mogamulizumab (Anti-CCR4) in HTLV-1-Associated Myelopathy. N. Engl. J. Med. 2018, 378, 529-538. [CrossRef] [PubMed]

319. Craig, J.M.; Macauley, J.C.; Weller, T.H.; Wirth, P. Isolation of intranuclear inclusion producing agents from infants with illnesses resembling cytomegalic inclusion disease. Proc. Soc. Exp. Biol. Med. 1957, 94, 4-12. [CrossRef] 
320. Smith, M.G. Propagation of salivary gland virus of the mouse in tissue cultures. Proc. Soc. Exp. Biol. Med. 1954, 86, 435-440. [CrossRef] [PubMed]

321. Mattes, F.M.; McLaughlin, J.E.; Emery, V.C.; Clark, D.A.; Griffiths, P.D. Histopathological detection of owl's eye inclusions is still specific for cytomegalovirus in the era of human herpesviruses 6 and 7. J. Clin. Pathol. 2000, 53, 612-614. [CrossRef] [PubMed]

322. Revello, M.G.; Gerna, G. Diagnosis and management of human cytomegalovirus infection in the mother, fetus, and newborn infant. Clin. Microbiol. Rev. 2002, 15, 680-715. [CrossRef]

323. Ho, M. The history of cytomegalovirus and its diseases. Med. Microbiol. Immunol. 2008, 197, 65-73. [CrossRef]

324. Boeckh, M.; Bowden, R.A.; Goodrich, J.M.; Pettinger, M.; Meyers, J.D. Cytomegalovirus antigen detection in peripheral blood leukocytes after allogeneic marrow transplantation. Blood 1992, 80, 1358-1364. [CrossRef]

325. Varnum, S.M.; Streblow, D.N.; Monroe, M.E.; Smith, P.; Auberry, K.J.; Pasa-Tolic, L.; Wang, D.; Camp, D.G., 2nd; Rodland, K.; Wiley, S.; et al. Identification of proteins in human cytomegalovirus (HCMV) particles: The HCMV proteome. J. Virol. 2004, 78, 10960-10966. [CrossRef]

326. Kotton, C.N.; Kumar, D.; Caliendo, A.M.; Huprikar, S.; Chou, S.; Danziger-Isakov, L.; Humar, A.; on behalf of the The Transplantation Society International CMV Consensus Group. The Third International Consensus Guidelines on the Management of Cytomegalovirus in Solid-organ Transplantation. Transplantation 2018, 102, 900-931. [CrossRef] [PubMed]

327. Geisler, J.; Touma, J.; Rahbar, A.; Soderberg-Naucler, C.; Vetvik, K. A Review of the Potential Role of Human Cytomegalovirus (HCMV) Infections in Breast Cancer Carcinogenesis and Abnormal Immunity. Cancers 2019, 11, 1842. [CrossRef]

328. Michaelis, M.; Doerr, H.W.; Cinatl, J. The story of human cytomegalovirus and cancer: Increasing evidence and open questions. Neoplasia 2009, 11, 1-9. [CrossRef]

329. Kumar, A.; Tripathy, M.K.; Pasquereau, S.; Al Moussawi, F.; Abbas, W.; Coquard, L.; Khan, K.A.; Russo, L.; Algros, M.P.; Valmary-Degano, S.; et al. The Human Cytomegalovirus Strain DB Activates Oncogenic Pathways in Mammary Epithelial Cells. EBioMedicine 2018, 30, 167-183. [CrossRef] [PubMed]

330. Salahuddin, S.Z.; Ablashi, D.V.; Markham, P.D.; Josephs, S.F.; Sturzenegger, S.; Kaplan, M.; Halligan, G.; Biberfeld, P.; Wong-Staal, F.; Kramarsky, B.; et al. Isolation of a new virus, HBLV, in patients with lymphoproliferative disorders. Science 1986, $234,596-601$. [CrossRef] [PubMed]

331. Yamanishi, K.; Okuno, T.; Shiraki, K.; Takahashi, M.; Kondo, T.; Asano, Y.; Kurata, T. Identification of human herpesvirus-6 as a causal agent for exanthem subitum. Lancet 1988, 1, 1065-1067. [CrossRef]

332. Wyatt, L.S.; Balachandran, N.; Frenkel, N. Variations in the replication and antigenic properties of human herpesvirus 6 strains. J. Infect. Dis. 1990, 162, 852-857. [CrossRef]

333. Ablashi, D.; Agut, H.; Alvarez-Lafuente, R.; Clark, D.A.; Dewhurst, S.; DiLuca, D.; Flamand, L.; Frenkel, N.; Gallo, R.; Gompels, U.A.; et al. Classification of HHV-6A and HHV-6B as distinct viruses. Arch. Virol. 2014, 159, 863-870. [CrossRef]

334. Ward, K.N.; Hill, J.A.; Hubacek, P.; de la Camara, R.; Crocchiolo, R.; Einsele, H.; Navarro, D.; Robin, C.; Cordonnier, C.; Ljungman, P.; et al. Guidelines from the 2017 European Conference on Infections in Leukaemia for management of HHV-6 infection in patients with hematologic malignancies and after hematopoietic stem cell transplantation. Haematologica 2019, 104, $2155-2163$. [CrossRef]

335. Saxinger, C.; Polesky, H.; Eby, N.; Grufferman, S.; Murphy, R.; Tegtmeir, G.; Parekh, V.; Memon, S.; Hung, C. Antibody reactivity with HBLV (HHV-6) in U.S. populations. J. Virol. Methods 1988, 21, 199-208. [CrossRef]

336. Okuno, T.; Takahashi, K.; Balachandra, K.; Shiraki, K.; Yamanishi, K.; Takahashi, M.; Baba, K. Seroepidemiology of human herpesvirus 6 infection in normal children and adults. J. Clin. Microbiol. 1989, 27, 651-653. [CrossRef] [PubMed]

337. Luppi, M.; Barozzi, P.; Morris, C.; Maiorana, A.; Garber, R.; Bonacorsi, G.; Donelli, A.; Marasca, R.; Tabilio, A.; Torelli, G. Human herpesvirus 6 latently infects early bone marrow progenitors in vivo. J. Virol. 1999, 73, 754-759. [CrossRef]

338. Luppi, M.; Marasca, R.; Barozzi, P.; Ferrari, S.; Ceccherini-Nelli, L.; Batoni, G.; Merelli, E.; Torelli, G. Three cases of human herpesvirus-6 latent infection: Integration of viral genome in peripheral blood mononuclear cell DNA. J. Med. Virol. 1993, 40, 44-52. [CrossRef]

339. Hermouet, S.; Minvielle, S. Inheritance of chromosomally integrated viral DNA? Blood 2000, 95, 1108-1109. [CrossRef] [PubMed]

340. Arbuckle, J.H.; Medveczky, M.M.; Luka, J.; Hadley, S.H.; Luegmayr, A.; Ablashi, D.; Lund, T.C.; Tolar, J.; De Meirleir, K.; Montoya, J.G.; et al. The latent human herpesvirus-6A genome specifically integrates in telomeres of human chromosomes in vivo and in vitro. Proc. Natl. Acad. Sci. USA 2010, 107, 5563-5568. [CrossRef]

341. Eliassen, E.; Lum, E.; Pritchett, J.; Ongradi, J.; Krueger, G.; Crawford, J.R.; Phan, T.L.; Ablashi, D.; Hudnall, S.D. Human Herpesvirus 6 and Malignancy: A Review. Front. Oncol. 2018, 8, 512. [CrossRef]

342. Kashanchi, F.; Araujo, J.; Doniger, J.; Muralidhar, S.; Hoch, R.; Khleif, S.; Mendelson, E.; Thompson, J.; Azumi, N.; Brady, J.N.; et al. Human herpesvirus 6 (HHV-6) ORF-1 transactivating gene exhibits malignant transforming activity and its protein binds to p53. Oncogene 1997, 14, 359-367. [CrossRef] [PubMed]

343. Lacroix, A.; Collot-Teixeira, S.; Mardivirin, L.; Jaccard, A.; Petit, B.; Piguet, C.; Sturtz, F.; Preux, P.M.; Bordessoule, D.; RangerRogez, S. Involvement of human herpesvirus-6 variant B in classic Hodgkin's lymphoma via DR7 oncoprotein. Clin. Cancer Res. 2010, 16, 4711-4721. [CrossRef] [PubMed]

344. Gu, B.; Li, M.; Zhang, Y.; Li, L.; Yao, K.; Wang, S. DR7 encoded by human herpesvirus 6 promotes glioma development and progression. Cancer Manag. Res. 2019, 11, 2109-2118. [CrossRef] 
345. Atchison, R.W.; Casto, B.C.; Hammon, W.M. Adenovirus-Associated Defective Virus Particles. Science 1965, 149, 754-756. [CrossRef]

346. Hoggan, M.D.; Blacklow, N.R.; Rowe, W.P. Studies of small DNA viruses found in various adenovirus preparations: Physical, biological, and immunological characteristics. Proc. Natl. Acad. Sci. USA 1966, 55, 1467-1474. [CrossRef] [PubMed]

347. Srivastava, A.; Lusby, E.W.; Berns, K.I. Nucleotide sequence and organization of the adeno-associated virus 2 genome. J. Virol. 1983, 45, 555-564. [CrossRef]

348. Dunbar, C.E.; High, K.A.; Joung, J.K.; Kohn, D.B.; Ozawa, K.; Sadelain, M. Gene therapy comes of age. Science 2018, 359. [CrossRef]

349. Montini, E.; Cesana, D.; Schmidt, M.; Sanvito, F.; Bartholomae, C.C.; Ranzani, M.; Benedicenti, F.; Sergi, L.S.; Ambrosi, A.; Ponzoni, M.; et al. The genotoxic potential of retroviral vectors is strongly modulated by vector design and integration site selection in a mouse model of HSC gene therapy. J. Clin. Investig. 2009, 119, 964-975. [CrossRef]

350. Baum, C.; Dullmann, J.; Li, Z.; Fehse, B.; Meyer, J.; Williams, D.A.; von Kalle, C. Side effects of retroviral gene transfer into hematopoietic stem cells. Blood 2003, 101, 2099-2114. [CrossRef]

351. Hacein-Bey-Abina, S.; Garrigue, A.; Wang, G.P.; Soulier, J.; Lim, A.; Morillon, E.; Clappier, E.; Caccavelli, L.; Delabesse, E.; Beldjord, K.; et al. Insertional oncogenesis in 4 patients after retrovirus-mediated gene therapy of SCID-X1. J. Clin. Investig. 2008, 118, 3132-3142. [CrossRef]

352. Raper, S.E.; Chirmule, N.; Lee, F.S.; Wivel, N.A.; Bagg, A.; Gao, G.P.; Wilson, J.M.; Batshaw, M.L. Fatal systemic inflammatory response syndrome in a ornithine transcarbamylase deficient patient following adenoviral gene transfer. Mol. Genet. Metab. 2003, 80, 148-158. [CrossRef] [PubMed]

353. Donsante, A.; Vogler, C.; Muzyczka, N.; Crawford, J.M.; Barker, J.; Flotte, T.; Campbell-Thompson, M.; Daly, T.; Sands, M.S. Observed incidence of tumorigenesis in long-term rodent studies of rAAV vectors. Gene Ther. 2001, 8, 1343-1346. [CrossRef]

354. Donsante, A.; Miller, D.G.; Li, Y.; Vogler, C.; Brunt, E.M.; Russell, D.W.; Sands, M.S. AAV vector integration sites in mouse hepatocellular carcinoma. Science 2007, 317, 477. [CrossRef] [PubMed]

355. Nault, J.C.; Datta, S.; Imbeaud, S.; Franconi, A.; Mallet, M.; Couchy, G.; Letouze, E.; Pilati, C.; Verret, B.; Blanc, J.F.; et al. Recurrent AAV2-related insertional mutagenesis in human hepatocellular carcinomas. Nat. Genet. 2015, 47, 1187-1193. [CrossRef]

356. Nguyen, G.N.; Everett, J.K.; Kafle, S.; Roche, A.M.; Raymond, H.E.; Leiby, J.; Wood, C.; Assenmacher, C.A.; Merricks, E.P.; Long, C.T.; et al. A long-term study of AAV gene therapy in dogs with hemophilia A identifies clonal expansions of transduced liver cells. Nat. Biotechnol. 2021, 39, 47-55. [CrossRef]

357. Bell, P.; Wang, L.; Lebherz, C.; Flieder, D.B.; Bove, M.S.; Wu, D.; Gao, G.P.; Wilson, J.M.; Wivel, N.A. No evidence for tumorigenesis of AAV vectors in a large-scale study in mice. Mol. Ther. 2005, 12, 299-306. [CrossRef] [PubMed]

358. Berns, K.I.; Byrne, B.J.; Flotte, T.R.; Gao, G.; Hauswirth, W.W.; Herzog, R.W.; Muzyczka, N.; VandenDriessche, T.; Xiao, X.; Zolotukhin, S.; et al. Adeno-Associated Virus Type 2 and Hepatocellular Carcinoma? Hum. Gene Ther. 2015, 26, 779-781. [CrossRef] [PubMed]

359. Gao, G.; Vandenberghe, L.H.; Alvira, M.R.; Lu, Y.; Calcedo, R.; Zhou, X.; Wilson, J.M. Clades of Adeno-associated viruses are widely disseminated in human tissues. J. Virol. 2004, 78, 6381-6388. [CrossRef] [PubMed] 